\title{
Evidence for efficient regenerated production and dinitrogen fixation in nitrogen-deficient waters of the South Pacific Ocean: impact on new and export production estimates
}

\author{
P. Raimbault and N. Garcia \\ Laboratoire de Microbiologie, Géochimie et Ecologie Marine (UMR 6117 CNRS), Centre d'Océanologie de Marseille, \\ Université de la Méditerranée, Campus de Luminy, 13288 Marseille, France
}

Received: 24 July 2007 - Published in Biogeosciences Discuss.: 5 October 2007

Revised: 8 January 2008 - Accepted: 24 January 2008 - Published: 5 March 2008

\begin{abstract}
One of the major objectives of the BIOSOPE cruise, carried out on the R/V Atalante from OctoberNovember 2004 in the South Pacific Ocean, was to establish productivity rates along a zonal section traversing the oligotrophic South Pacific Gyre (SPG). These results were then compared to measurements obtained from the nutrient - replete waters in the Chilean upwelling and around the Marquesas Islands. A dual ${ }^{13} \mathrm{C} /{ }^{15} \mathrm{~N}$ isotope technique was used to estimate the carbon fixation rates, inorganic nitrogen uptake (including dinitrogen fixation), ammonium $\left(\mathrm{NH}_{4}\right)$ and nitrate $\left(\mathrm{NO}_{3}\right)$ regeneration and release of dissolved organic nitrogen (DON). The SPG exhibited the lowest primary production rates $\left(0.15 \mathrm{~g} \mathrm{C} \mathrm{m}^{-2} \mathrm{~d}^{-1}\right)$, while rates were 7 to 20 times higher around the Marquesas Islands and in the Chilean upwelling, respectively. In the very low productive area of the SPG, most of the primary production was sustained by active regeneration processes that fuelled up to $95 \%$ of the biological nitrogen demand. Nitrification was active in the surface layer and often balanced the biological demand for nitrate, especially in the SPG. The percentage of nitrogen released as DON represented a large proportion of the inorganic nitrogen uptake (13-15\% in average), reaching 26$41 \%$ in the SPG, where DON production played a major role in nitrogen cycling. Dinitrogen fixation was detectable over the whole study area; even in the Chilean upwelling, where rates as high as 3 nmoles $1^{-1} \mathrm{~d}^{-1}$ were measured. In these nutrient-replete waters new production was very high $\left(0.69 \pm 0.49 \mathrm{~g} \mathrm{C} \mathrm{m}^{-2} \mathrm{~d}^{-1}\right)$ and essentially sustained by nitrate levels. In the SPG, dinitrogen fixation, although occurring at much lower daily rates $\left(\approx 1-2\right.$ nmoles $\left.1^{-1} \mathrm{~d}^{-1}\right)$, sustained up to $100 \%$ of the new production $\left(0.008 \pm 0.007 \mathrm{~g} \mathrm{C} \mathrm{m}^{-2} \mathrm{~d}^{-1}\right)$ which was two orders of magnitude lower than that measured in the upwelling. The annual $\mathrm{N}_{2}$-fixation of the South Pacific
\end{abstract}

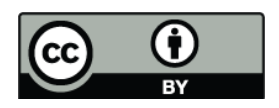

Correspondence to: P. Raimbault (patrick.raimbault@univmed.fr) is estimated to $21 \times 10^{12} \mathrm{~g}$, of which $1.34 \times 10^{12} \mathrm{~g}$ is for the SPG only. Even if our "snapshot" estimates of $\mathrm{N}_{2}$-fixation rates were lower than that expected from a recent ocean circulation model, these data confirm that the N-deficiency South Pacific Ocean would provide an ideal ecological niche for the proliferation of $\mathrm{N}_{2}$-fixers which are not yet identified.

\section{Introduction}

The nitrogen cycle in the oceanic gyres has been studied ever since the pioneering work of Menzel and Ryther in the Sargasso Sea (Menzel and Ryther, 1960; Ryther and Menzel, 1961). Several years later, Dugdale and Goering (1967) defined new and regenerated nitrogen and hence new production, fuelled by allochthonous $\mathrm{N}$-sources (mainly $\mathrm{NO}_{3}^{-}$) supplied by diffusion from the nitracline. Regenerated production, on the other hand, is fuelled by autochthonous $\mathrm{N}$ sources (mainly $\mathrm{NH}_{4}^{+}$), derived from biological processes (Harrison et al., 1987). The fraction of primary production derived from "new nutrients" is termed the f-ratio (Eppley and Peterson, 1979) and when in a steady state, accounts for the proportion of production available for export. Historically, measurements of the nitrogen cycle were primarily based on ${ }^{15} \mathrm{~N}$ tracer techniques. New production estimates, computed in terms of carbon using the f-ratio and primary production, have shown considerable variations (Aufdenkampe et al., 2002), due to inaccuracies in estimating $f$ and $\mathrm{NO}_{3}^{-}$assimilation (Priscu and Downes, 1985; Ward et al., 1989; Gentilhomme and Raimbault, 1994; Raimbault et al., 1999; Diaz and Raimbault, 2000; Aufdenkampe et al., 2001).

The main sources of error in classical ${ }^{15} \mathrm{~N}$ uptake experiments are still being debated, in particular nitrogen regeneration and the release of dissolved organic nitrogen (DON), which have evoked several revisions on the concepts of new and regenerated production. Ammonium regeneration is the

Published by Copernicus Publications on behalf of the European Geosciences Union. 
main source of regenerated nitrogen in the euphotic zone. By studying ammonium isotopic dilution (recycling of unlabeled substrate) during ${ }^{15} \mathrm{~N}$ incubation experiments, Glibert et al. (1982), and Harrison et al. (1987) showed that ammonium regeneration can result in significant underestimations of regenerated production, which would also bias the assessment of the f-ratio. Nitrification (the oxidation of $\mathrm{NH}_{4}$ to $\mathrm{NO}_{3}$ by bacteria) is also an important variable, responsible for maintaining the deep sea nitrate reservoir and also believed to provide a source of "in situ" regenerated nitrate at the base of the euphotic zone (where phytoplankton is light limited and competes for $\mathrm{NH}_{4}^{+}$; see review in Ward 2000). Until recently, nitrification was considered to be restricted to specific environments but over the last decade it has been found to be more widely distributed (Zehr and Ward, 2002; Lomas and Lipschultz, 2006). The failure in estimating dissolved inorganic nitrogen (DIN) taken up by phytoplankton and released as DON presents another and not entirely resolved source of error in DIN uptake rates (Bronk et al., 1994; Slawyk and Raimbault, 1995). However, the impact of such processes is rarely reported as a possible factor for overestimation in new production calculations. Finally, oceanographers have traditionally viewed the upward eddydiffusive flux of nitrate as the exclusive source of new nitrogen supporting the export flux of biogenic particles in the open oceans. In fact, the ubiquitous pool of dinitrogen gas $\left(\mathrm{N}_{2}\right)$ dissolved in the sea can represent a significant source of new nitrogen. Recently, estimates of biological nitrogen fixation have been revised and are much higher than originally thought (Galloway et al., 1995; Grüber and Sarmiento, 1997; Capone and Carpenter, 1982). In the north subtropical and tropical Atlantic and Pacific Oceans, it has been estimated that $\mathrm{N}_{2}$ fixation contributes to $50-180 \%$ of the nitrate flux into the photic zone (Capone et al., 2005), demonstrating that a large proportion of new primary production is fuelled by $\mathrm{N}_{2}$ fixation rather than from deep nitrate diffusing from the deeper layers into the photic zone. While the large size classes (Trichodesmium and diatoms containing endosynbiotic Richelia) are thought to be responsible for the vast majority of $\mathrm{N}_{2}$ fixation, recent work by Zehr et al. (2001) has found a nifH gene in the nanoplanktonic fraction. These small diazotrophic organisms, while present at low cellular concentration, could sustain a large proportion of the new production under nitrate-deplete conditions (Montoya et al., 2004; Falcon et al., 2004; Garcia et al., 2006, 2007). Representing $60 \%$ of the global ocean's area, the subtropical open-ocean ecosystems are the largest coherent biomes of our planet and the biogeochemical processes they support have global consequences (Karl, 2002). These environments provide an ideal ecological niche for the development of nitrogen-fixing organisms. To date, studies dedicated to nutrient control on nitrogen fixation have concentrated on the Northern Hemisphere and there is very little data available for the Southern Hemisphere, which contains the largest ocean area globally. Deutsch et al. (2007), using an ocean circulation model associated with the climatological distribution of nitrate and phosphate, demonstrated that nitrogen rates were highest in the Pacific Ocean and were closely related to the generation of nitrogen-deficient waters. In this context, the BIOSOPE (BIOgeochemistry and Optics South Pacific Experiment) cruise was scheduled to provide a complete data set of biogeochemical parameters in the South Pacific Ocean, characterized by a marked nitrogen-deficiency (Deutsch et al., 2007; Raimbault et al., 2007). In addition, the South Pacific Central Gyre has been described as the most oligotrophic zone in the world's oceans (Claustre and Maritorena, 2003), exhibiting extreme nutrient limitation. It is also one of the least studied areas of the Ocean (Daneri and Quinones, 2001). The 8000-km transect, stretching from the Marquesas Islands to the Chilean coast and crossing the centre of the South Pacific Gyre, was chosen because it is an ideal area for studying primary production and new production along extreme trophic gradients. This work focuses on the geographical distribution of photosynthetic carbon fixation, nitrogen assimilation (including dinitrogen fixation and release of dissolved organic nitrogen) and nitrogen regeneration in the photic zone of the South Pacific Ocean and across a section spanning a wide range of trophic status (from nutrient enriched to severely nutrient impoverished), in order to estimate primary production and the f-ratio correctly, i.e. determining the part that was sustained by "new" nitrogen. Additionally, it provides an objective methodological approach for estimating new production in oligotrophic systems.

\section{Methods}

This work was carried out on board the R/V Atalante during October-November 2004. Data was collected during the BIOSOPE (BIOgeochemistry and Optics South Pacific experiment) cruise carried out in the southeast Pacific Ocean along a transect stretching from the Marquesas archipelago to the Chilean coast (between $146.36 \mathrm{~W}$ and $72.49^{\circ} \mathrm{W}$, Fig. 1).

Twenty-four short-stay stations were sampled along an $8000-\mathrm{km}$ transect crossing different oceanic regimes. These were the mesotrophic area associated with the plume off the Marquesas Island $\left(141^{\circ} \mathrm{W}-134^{\circ} \mathrm{W}\right)$, the adjacent high nitrate - low chlorophyll waters $\left(132^{\circ}-123^{\circ} \mathrm{W}\right)$, the ultraoligotrophic waters associated with the central part of the south pacific gyre $\left(123^{\circ} \mathrm{W}-101^{\circ} \mathrm{W}\right)$, the oligotrophic eastern side of the gyre $\left(101^{\circ} \mathrm{W}-81^{\circ} \mathrm{W}\right)$ and the Chilean upwelling $\left(80^{\circ} \mathrm{W}-72^{\circ} \mathrm{W}\right)$. In addition, six experimental sites were specifically investigated with long-stay, fixed stations (over 2-5 days), representing sites of different trophic regimes: MAR $=$ Marquesas archipelago $\left(141.3^{\circ} \mathrm{W} ; 8.4^{\circ} \mathrm{S}\right)$; HLNC $=$ High Nutrient Low Chlorophyll area east of the Marquesas islands $\left(136.8^{\circ} \mathrm{W} ; 9^{\circ} \mathrm{S}\right)$; GYR $=$ centre of the South Pacific Gyre $114^{\circ} \mathrm{W}, 26^{\circ} \mathrm{S}$ ); EGY = eastern border of the gyre $\left(91.4^{\circ} \mathrm{W}, 31.8^{\circ} \mathrm{S}\right)$, UPW and UPX situated in the area of a Chilean upwelling $\left(73^{\circ} \mathrm{W}-34^{\circ} \mathrm{S}\right.$ and $\left.72.4^{\circ} \mathrm{W}-34.5^{\circ} \mathrm{S}\right)$. The 


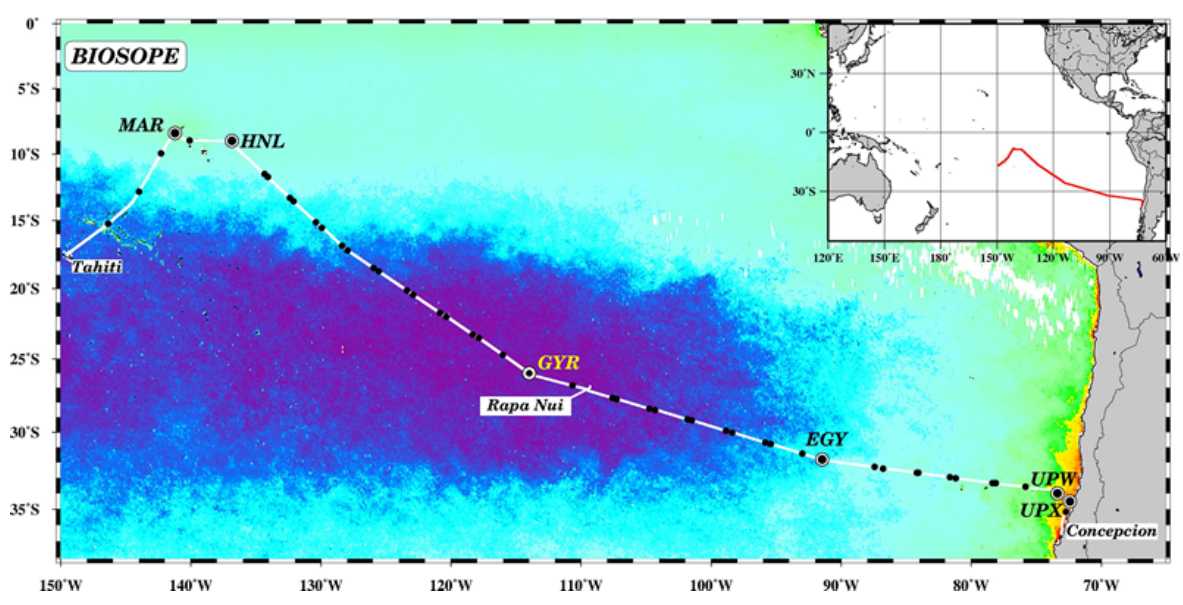

Fig. 1. Map showing the location of the BIOSOPE cruise from Marquises Island to Chile superimposed on a SeaWiFS surface Chl- $a$ composite (November-December 2004). Locations of CTD casts are indicated by dark points and long time experimental stations by large circles. $\quad\left(\mathrm{MAR}=141.3^{\circ} \mathrm{W} ; 8.4^{\circ} \mathrm{S} ; \mathrm{HLN}=136.8^{\circ} \mathrm{W} ; 9^{\circ} \mathrm{S} ; \mathrm{GYR}=114^{\circ} \mathrm{W} ; 26^{\circ} \mathrm{S}\right)$; EGYR $=$ eastern border of the gyre $\left(91.4^{\circ} \mathrm{W}, 31.8^{\circ} \mathrm{S}\right.$; $\mathrm{UPW}=73^{\circ} \mathrm{W}-34^{\circ} \mathrm{S}$ and $\mathrm{UPX}=72.4^{\circ} \mathrm{W}-34.5^{\circ} \mathrm{S}$ ).

station situated in the gyre was selected using ocean colour images, and has the lowest surface chlorophyll concentration in the world's ocean.

Nutrient measurements were performed at every station of the grid. For nitrate and nitrite determination, samples were taken into 250-ml polyethylene flasks and analyzed on board immediately using a semiautomatic Technicon Autonanalyser ${ }^{\circledR}$ II, according to Raimbault et al. (1990), for both low-nitrate waters $\left(<500\right.$ nmoles $1^{-1}$; detection limit $=$ 3 nmoles $1^{-1}$ ) and for high-nitrate waters $\left(>500\right.$ nmoles $1^{-1}$; detection limit $=0.05 \mu$ moles $1^{-1}$ ) according to Tréguer and le Corre (1975). Ammonium concentrations (40 ml collected in $50 \mathrm{ml}$ Schott glass bottles) were measured using the fluorometric method (Holmes et al., 1999; detection limit = $0.005 \mu$ moles $\left.1^{-1}\right)$.

At each productivity station, rates of carbon fixation (primary production), nitrate and ammonium uptake and dinitrogen fixation (diazotrophy) were measured using a dual ${ }^{13} \mathrm{C} /{ }^{15} \mathrm{~N}$ isotopic technique. For this purpose, three $580-\mathrm{ml}$ samples were collected before sunrise at 6 depths between the surface and 1\% light irradiance/incidence and poured into acid-cleaned polycarbonate flasks. Bottles were rinsed after use with $10 \% \mathrm{HCl}$, then with distilled water from a Milli $\mathrm{Q}$ ion exchange unit. Labelled ${ }^{13} \mathrm{C}$ sodium bicarbonate $\left(\mathrm{NaH}^{13} \mathrm{CO}_{3}-6 \mathrm{~g} 250 \mathrm{ml}^{-1}\right.$ deionized water -99 at $\%$ ${ }^{13} \mathrm{C}$, EURISOTOP) was added to each bottle in order to obtain an $\approx 10 \%$ final enrichment $\left(0.5 \mathrm{ml} 580 \mathrm{ml}^{-1}\right.$ sea water $)$. ${ }^{15} \mathrm{~N}_{2}$ gas (99 at $\%{ }^{15} \mathrm{~N}$, EURISOTOP) was then bubbled into gas tight bottles ( $2 \mathrm{ml}$ of gas $580 \mathrm{ml}^{-1}$ sea water). We added a fixed quantity of ${ }^{15} \mathrm{~N}_{2}$ gas and calculated the enrichment of each bottle on the basis of its volume and the solubility of $\mathrm{N}_{2}$. We used the equations provided by Weiss (1970) to calculate the initial $\mathrm{N}_{2}$ concentration, assuming equilibrium with the atmosphere. The ${ }^{15} \mathrm{~N}_{2}$ enrichments ranged between $22 \%$ and $25 \%$ in seawater, where temperatures varied from $15^{\circ} \mathrm{C}$ (in the upwelling) to $27^{\circ} \mathrm{C}$ (in the subequatorial zone). The samples were then carefully shaken to ensure rapid equilibration between ${ }^{15} \mathrm{~N}_{2}$ and natural $\mathrm{N}_{2}$.

Nitrogen ${ }^{15} \mathrm{~N}$-tracer additions, $\mathrm{K}^{15} \mathrm{NO}_{3}$ or ${ }^{15} \mathrm{NH}_{4} \mathrm{Cl}(99 \%$ at ${ }^{15} \mathrm{~N}$ ), were $10 \%$ or $20 \%$ of the ambient concentration based on real-time measurements. In nutrient impoverished waters, when concentrations were lower than the detection limit, additions of ${ }^{15} \mathrm{~N}$ were fixed at $\sim 17$ nmoles $\mathrm{l}^{-1}$ for ${ }^{15} \mathrm{~N}-\mathrm{NO}_{3}$ and 43 nmoles $1^{-1}$ for ${ }^{15} \mathrm{~N}-\mathrm{NH}_{4}$.

Incubations were carried out immediately following tracer addition, just before dawn in an on-deck incubator. This consisted of 6-7 opaque boxes, each with a light screen, allowing $50 \%, 25 \%, 15 \%, 8 \%, 4 \%, 1 \%$ and $0.3 \%$ light penetration. The incubator was maintained at sea-surface temperature using pumped sea water. At each of the 5 experimental sites, incubations were performed in situ on a drifting rig situated at the same depth from which the samples were collected. After $24 \mathrm{~h}$ (dawn to dawn), final concentrations of $\mathrm{NO}_{3}^{-}$and $\mathrm{NH}_{4}^{+}$were measured and samples were filtered through precombusted $\left(450^{\circ} \mathrm{C}\right)$ Whatman $\mathrm{GF} / \mathrm{F}$ filters $(25 \mathrm{~mm}$ in diameter, nominal porosity $\approx 0.7 \mu \mathrm{m})$, using a low vacuum pressure $(<100 \mathrm{~mm} \mathrm{Hg})$. The ${ }^{15} \mathrm{~N}_{-} \mathrm{NH}_{4}$ filtrates were collected in Duran Schott glass flasks and poisoned with $1 \mathrm{ml} \mathrm{HgCl}_{2}$ $\left(6 \mathrm{~g} \mathrm{l}^{-1}\right)$ in order to prevent bacterial activity during storage; 200-ml aliquots of these filtrates were also filtered through $0.2 \mu \mathrm{m}$ Teflon membranes. ${ }^{15} \mathrm{~N}$-nitrate filtrates were collected during in situ experiments, only. In this case $300 \mathrm{ml}$ of GF/F filtrate was filtered through $0.2-\mu \mathrm{m}$ Teflon membranes and stored as above. Following filtration, filters were placed into $2-\mathrm{ml}$ glass tubes, dried for $24 \mathrm{~h}$ in a $60^{\circ} \mathrm{C}$ oven and stored dry until laboratory analysis. These filters were 
used to determine the final ${ }^{15} \mathrm{~N} /{ }^{13} \mathrm{C}$ enrichment ratio in the particulate organic matter and the concentrations of particulate carbon and particulate nitrogen.

The dual isotopic enrichment analysis was performed on an Integra-CN mass spectrometer, calibrated using glycine references for every batch of 10-15 samples. The accuracy of our analytical system was also regularly verified using reference materials from the International Atomic Energy Agency (AIEA, Analytical Quality Control Services). The mean ${ }^{15} \mathrm{~N}$ atom $\%$ did not vary between 0.2 and $10 \mu$ moles $\mathrm{N}$. Thus, the low background of the system gave an accurate analyse for samples containing low nitrogen concentrations $(0.1-0.2 \mu$ mole $)$, values often observed in surface oligotrophic waters. The ${ }^{15} \mathrm{~N}$ isotope enrichment of a sample is reported in terms of the ratio of ${ }^{15} \mathrm{~N}$ atom $\%$ excess overtime, over the ${ }^{15} \mathrm{~N}$ atom $\%$ in non-enriched samples taken from the same phytoplankton population at time zero. The value of time zero enrichment is vital and was determined using samples (same volume as the incubated sample) which were filtered immediately after isotope addition. For $\mathrm{N}_{2}$ experiments, the time zero value, established using 8 samples, was $0.3676 \pm 0.007 \%$. For ${ }^{15} \mathrm{~N}-\mathrm{NO}_{3}$ and ${ }^{15} \mathrm{~N}-\mathrm{NH}_{4}$ experiments, time 0 enrichment was $0.372 \pm 0.007 \%$. We considered the results to be significant when ${ }^{15} \mathrm{~N}$ excess enrichments were greater than $0.014 \%$ (two times the standard deviation obtained with time zero samples).

The transport rate of ${ }^{15} \mathrm{~N}$-labelled dissolved inorganic nitrogen (DIN), from the DIN pool to the PON pool, i.e. the net DIN uptake $\left(\rho_{\text {DIN }}^{\text {net }}\right.$ in nmoles $\left.1^{-1} \mathrm{~d}^{-1}\right)$ was computed, according to Dugdale and Wilkerson (1986), from Eq. (1):

$\rho_{\mathrm{DIN}}^{\mathrm{net}}=\frac{R_{\mathrm{PON}}}{R_{\mathrm{DIN}} \times T} \times[\mathrm{PON}]$,

where $R_{\mathrm{PON}}$ and $R_{\mathrm{DIN}}$ represent the ${ }^{15} \mathrm{~N}$ atom $\%$ excess enrichment in the PON and DIN pools, respectively, [PON] represents the final PON concentration and $T$ represents the incubation time (in days). To correct ammonium uptake rates for isotopic dilution, we made $R_{\mathrm{DIN}}$ in Eq. (1) equal to the mean value obtained between initial and final $R_{\mathrm{NH}_{4}}$. According to these experimental conditions, the detection limit for nitrogen uptake, calculated from significant enrichment $(0.014 \%$ in excess) and lowest particulate nitrogen $(0.2 \mu$ mole $\mathrm{N})$ is estimated from Eq. (1) to be $0.12 \mathrm{nmol}^{-1} \mathrm{~d}^{-1}$ for nitrogen-fixation (mean $R_{\mathrm{DIN}} \approx 24 \%$ ) and $0.03 \mathrm{nmoll}^{-1} \mathrm{~d}^{-1}$ for nitrate and ammonium uptake in nutrient-depleted waters $\left(R_{\mathrm{DIN}} \approx 100 \%\right)$.

Carbon fixation rates were calculated according to Slawyk and Collos (1984), with a time 0 enrichment of $1.113 \pm 0.005 \% \quad(n=8)$. This time 0 value is little higher than the natural abundance for phytoplankton (1.089), due to residual traces of ${ }^{13} \mathrm{C}$ tracer. It should be noted that the ${ }^{13} \mathrm{C}$ enrichment of samples was less problematic than the ${ }^{15} \mathrm{~N}$ enrichment, since inorganic carbon is assimilated by the whole phytoplankton population and excess values ranged from 0.3 to $3.6 \%$. Fixation rates for ${ }^{13} \mathrm{C}$, i.e. primary production, were calculated from the mean of three replicates and are expressed in $\mu \mathrm{g} \mathrm{Cl}^{-1} \mathrm{~d}^{-1}$. Applying a similar calculation as that for nitrogen, the detection limit is estimated to be $0.35 \mu \mathrm{g} \mathrm{Cl}^{-1} \mathrm{~d}^{-1}$.

$\mathrm{GF} / \mathrm{F}$ filtrates from the ${ }^{15} \mathrm{NH}_{4}$ incubations were used to measure the final ${ }^{15} \mathrm{~N}$ enrichment 1) in the DIN pool and 2) in the $<0.7 \mu \mathrm{m}$ organic matter pool, as outlined by Raimbault et al. (1999). In this procedure, all forms of DIN are removed from the sample as $\left(\mathrm{NH}_{4}\right)_{2} \mathrm{SO}_{4}$, by successive diffusion and reduction processes. The first diffusion step enables us to quantify the final ${ }^{15} \mathrm{~N}$ enrichment of the ammonium pool, and the estimation of the isotope dilution of the tracer due to $\mathrm{NH}_{4}$ regeneration. During the second diffusion, the ${ }^{15} \mathrm{~N}$ enrichment of the nitrate pool in the ammonium filtrates enables us to quantify the oxidation of ammonium to nitrate (nitrification). During the third diffusion, the ${ }^{15} \mathrm{~N}$ enrichment was determined in the fraction passing through GF/F to estimate the rate of ${ }^{15} \mathrm{~N}-\mathrm{NH}_{4}$ accumulation in the $<0.7 \mu \mathrm{m}$ organic matter (dissolved organic nitrogen $+<0.7 \mu \mathrm{m}$ particulate nitrogen). The $<0.2 \mu \mathrm{m}$ filtrates from ${ }^{15} \mathrm{~N}-\mathrm{NH}_{4}$ and ${ }^{15} \mathrm{~N}-\mathrm{NO}_{3}$ experiments were used to measure ${ }^{15} \mathrm{~N}$ enrichment in the $<0.2 \mu \mathrm{m}$ fraction which only contains dissolved organic nitrogen (DON), in order to estimate tracer loss in terms of DON $\left(\rho_{\text {DIN }}^{\text {loss }}\right)$.

Ammonium regeneration rates $\left(r \mathrm{NH}_{4}\right.$ in nmoles $\left.\mathrm{l}^{-1} \mathrm{~d}^{-1}\right)$ were estimated according to Laws (1984):

$r \mathrm{NH}_{4}=\frac{\left[\mathrm{NH}_{4}\right]_{I}+\left[\mathrm{NH}_{4}\right]_{F}}{2 * T} * \ln \left(\frac{R o_{\mathrm{NH}_{4}}}{R f_{\mathrm{NH}_{4}}}\right)$,

where $\left[\mathrm{NH}_{4}\right]_{I}$ and $\left[\mathrm{NH}_{4}\right]_{F}$ represent initial and final concentrations of ammonium during the incubation experiment. $R o_{\mathrm{NH}_{4}}$ and $R f_{\mathrm{NH}_{4}}$ are the initial and final excess enrichments in ${ }^{15} \mathrm{~N}-\mathrm{NH}_{4}$ for the incubation period.

Nitrification rates $\left(\rho_{\text {NIT }}\right.$ in nmoles $l^{-1} \mathrm{~d}^{-1}$ ) were computed according to Raimbault et al. (1999):

$\rho_{\mathrm{NIT}}=\frac{R_{\mathrm{NO}_{3}}}{R_{\mathrm{NH}_{4}} \times T} \times\left[\mathrm{NO}_{3}\right]$,

where $R_{\mathrm{NO}_{3}}$ is the ${ }^{15} \mathrm{~N}$ atom $\%$ excess enrichment in the $\left(\mathrm{NO}_{3}^{-}+\mathrm{NO}_{2}^{-}\right)$pool, $R_{\mathrm{NH}_{4}}$ is the mean ${ }^{15} \mathrm{~N}$ atom $\%$ excess enrichment of the $\mathrm{NH}_{4}^{+}$pool, and $\left[\mathrm{NO}_{3}\right]$ is the final $\mathrm{NO}_{3}^{-}$concentration in the filtrate.

The measurement of ${ }^{15} \mathrm{~N}$ abundance in the organic matter collected in the $<\mathrm{GF} / \mathrm{F}$ filtrate $\left(R_{<\mathrm{GF} / \mathrm{F}}\right)$ enabled us to calculate ammonium uptake in the $<0.7 \mu \mathrm{m}$ fraction $\left(\rho_{\mathrm{NH}_{4}}^{<\mathrm{GF} / \mathrm{F}}\right)$, calculated as following (Eq. 4):

$\rho_{\mathrm{NH}_{4}}^{<\mathrm{GF} / \mathrm{F}}=\frac{R_{<\mathrm{GF} / \mathrm{F}}}{R_{\mathrm{NH}_{4}} \times T} \times\left[\mathrm{PON}_{<\mathrm{GF} / \mathrm{F}}\right]$,

where $R_{<\mathrm{GF} / \mathrm{F}}$ and $R_{\mathrm{NH}_{4}}$ are the ${ }^{15} \mathrm{~N}$ atom $\%$ excess enrichment of the $<\mathrm{GF} / \mathrm{F}$ fraction and final ammonium pool, respectively, and $\left[\mathrm{PON} \mathrm{N}_{<\mathrm{GF} / \mathrm{F}]}\right.$ is the final particulate nitrogen in the GF/F filtrate. The measurement of ${ }^{15} \mathrm{~N}$ abundance in 

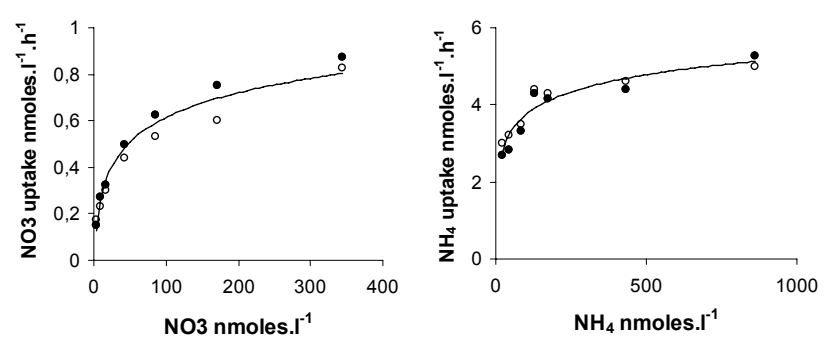

Fig. 2. Rates of nitrate and ammonium uptake $\left(\right.$ nmoles $\left.l^{-1} h^{-1}\right)$ as a function of nitrate and ammonium additions in nutrient-depleted waters. Experiments were performed during two successive days with surface waters of the South Pacific Gyre $\left(114^{\circ} \mathrm{W}-26^{\circ} \mathrm{S}\right)$.

the extracellular DON pool $\left(R_{\mathrm{DON}}\right)$ enabled us to calculate the DIN (nitrate or ammonium) lost ( $\left.\rho_{\text {DIN }}^{\text {loss }}\right)$ as DON (Eq. 5), calculated as outlined by Slawyk et al. (1998):

$\rho_{\mathrm{DIN}}^{\text {loss }}=\frac{R_{\mathrm{DON}}}{R_{\mathrm{DIN}} \times T} \times[\mathrm{DON}]$,

where $R_{\mathrm{DON}}$ and $R_{\mathrm{DIN}}$ are the ${ }^{15} \mathrm{~N}$ atom $\%$ excess enrichment of the extracellular DON and DIN pool, respectively, and $[\mathrm{DON}]$ is the final extracellular DON concentration. The quantification of the $\rho_{\mathrm{DIN}}^{\text {loss }}$ offers the possibility for calculating the gross uptake rate $\rho_{\text {DIN }}^{\text {loss }}$ as the sum of the net DIN uptake and the DIN loss:

$\rho_{\text {DIN }}^{\text {gross }}=\rho_{\text {DIN }}^{\text {net }}+\rho_{\text {DIN }}^{\text {loss }}$.

During this study, nitrate and ammonium concentrations were often lower than the detection limit (especially in the South Pacific Gyre) and it was experimentally impossible to reduce the addition of the tracer to the ideal level $(<10 \%$ of ambient concentration). In these nutrient conditions, the tracer addition violates the general assumption that the tracer addition does not disturb the steady-state of the system and could well have evoked a major perturbation in the nitrate and ammonium uptake (Allen et al., 2002; Harrison et al., 1996). Despite this, the use of kinetic parameters, described by Harrison et al. (1996), enabled us to account for the uptake rate enhancement according to the following equation given by Rees et al. (1999),

$\rho \mathrm{N}_{H}=\rho \mathrm{N}_{0} /\left[\mathrm{N}_{s p} /\left(K s+\mathrm{N}_{s p}\right) \times\left(K s+\mathrm{N}_{A}\right) / \mathrm{N}_{A}\right]$,

where $\mathrm{N}$ is nitrate or ammonium, $\rho \mathrm{N}_{0}$ is the original uptake rate (nmoles $1^{-1} \mathrm{~d}^{-1}$ ), $\rho \mathrm{N}_{H}$ is the uptake rate adjusted for enhancement of tracer, $\mathrm{N}_{s p}$ is the ambient + tracer nutrient (nmoles), $\mathrm{N}_{A}$ is the ambient nutrient and $K s$ is the half-saturation constant. In this case, $\mathrm{N}_{A}$ was assumed to be 3 nmoles $1^{-1}$ for nitrate and 5 nmoles $^{-1}$ for ammonium, corresponding to the detection limit of our analytical procedures. To quantify the affinity constant $K s$, two kinetic studies were performed with 6 graduated additions of ${ }^{15} \mathrm{~N}$-labeled substrate (Fig. 2). A Monod equation

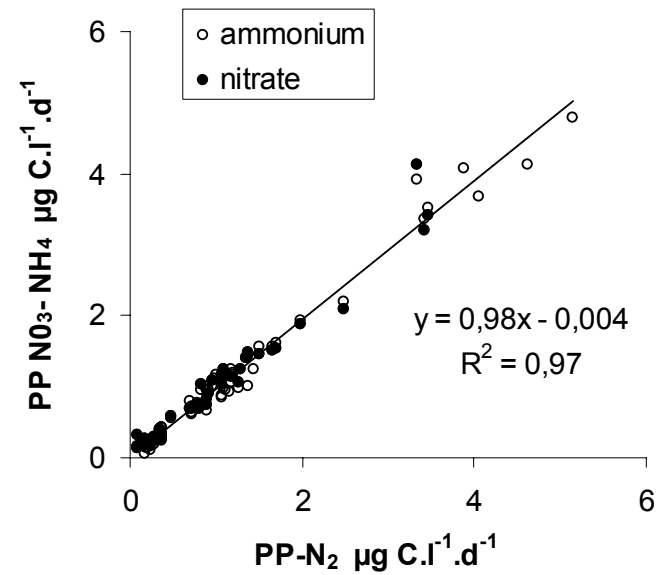

Fig. 3. Comparison between primary production $\left(\mathrm{mg} \mathrm{C} \mathrm{m}^{-3} \mathrm{~d}^{-1}\right)$ measured in nutrient-depleted samples, e.g. without nutrient additions $\left(\mathrm{PPN} \mathrm{N}_{2}\right)$, and those $\left(\mathrm{PPNO}_{3}-\mathrm{NH}_{4}\right)$ spiked with nitrate $\left(17\right.$ nmoles $\left.1^{-1}\right)$ or ammonium $\left(43\right.$ nmoles $\left.1^{-1}\right)$. The solid line is the model II linear regression.

$[V=V m S /(K s+S)]$ was assumed, where $V$ is the uptake rate for substrate concentration $S, V m$ is the saturated uptake rate and $K_{S}$, the affinity constant, e.g. the substrate concentration at half $V m$. The kinetics constant $K_{S}$, needed for the use of Rees et al.'s model, was derived from the Wolf plot linear transformation of $S / V$ vs. $S$. $K s$ obtained during 4 experiments performed in nitrogen-depleted waters (12.9 and 15 nmoles $1^{-1}$ for nitrate and ammonium, respectively) were a little lower than those measured in other oceanic waters (around 25-30 nmoles $1^{-1}$ ) by Sahlsten (1987) and Harrison et al. (1996). As a first approximation, we assumed that DIN losses as DON $\left(\rho_{\text {DIN }}^{\text {loss }}\right)$ and nitrification $\left(\rho_{\text {NIT }}\right)$ could be activated in the same way as net uptake rates and we applied the same procedure of correction to these processes.

In addition, spiked nutrient additions in nutrient-limited waters could also stimulate ${ }^{13} \mathrm{C}$ fixation. Thus samples enriched with ${ }^{15} \mathrm{~N}-\mathrm{N}_{2}$, which did not significantly change the $\mathrm{N}_{2}$ concentration of the samples, were used as a control for the stimulation of primary production by ${ }^{15} \mathrm{~N}$-tracer additions in oligotrophic waters (Fig. 3). Model II gives a regression coefficient of 0.98 , revealing no significant stimulation of primary production by low nutrient addition, at least over the $24 \mathrm{~h}$ experiments. As the ${ }^{13} \mathrm{C}$ isotope is not routinely used for estimating marine productivity, especially in oligotrophic oceanic areas, our results $\left(\mathrm{PP}^{13} \mathrm{C}\right)$ also offered the opportunity to carry out an extensive comparison with classical primary production measurements using a ${ }^{14} \mathrm{C}$ tracer $\left(\mathrm{PP}^{14} \mathrm{C}\right)$ in the same conditions (T. Moutin, personal communication). On pooling all the data collected during in situ experiments and using the model II linear regression, we noted the significant relationships $\left(\mathrm{PP}^{13} \mathrm{C}=1.02 \mathrm{PP}^{14} \mathrm{C}+0.14\right.$, $r^{2}=0.98 ; n=50$ ), which indicated the efficiency of the ${ }^{13} \mathrm{C}$ procedure in quantifying the photosynthetic carbon fixation in oligotrophic waters. 

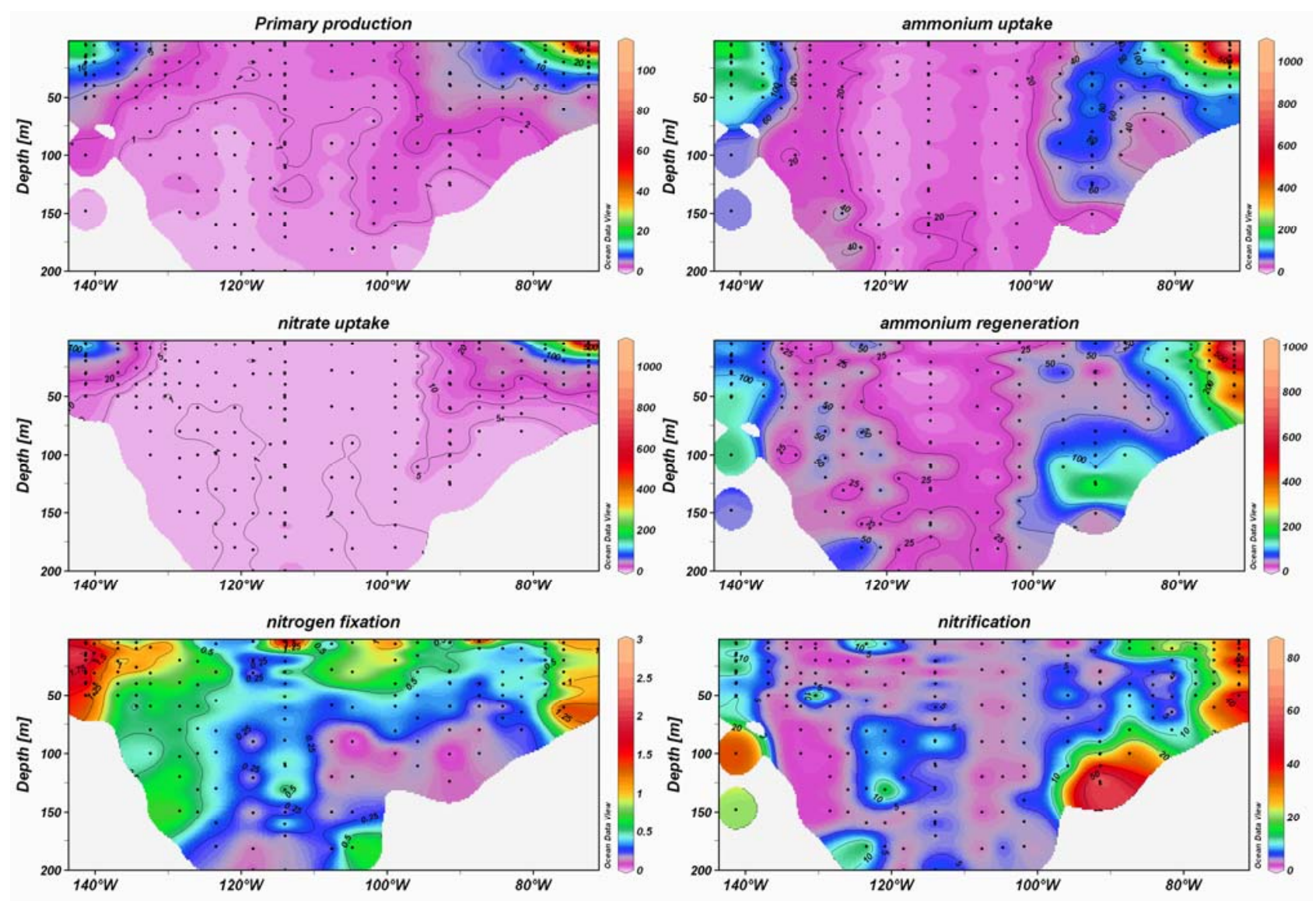

Fig. 4. Zonal sections of primary production $\left(\mu \mathrm{gCl}^{-1} \mathrm{~d}^{-1}\right)$, nitrate uptake (nmoles $1^{-1} \mathrm{~d}^{-1}$ ), ammonium uptake (nmoles $\mathrm{N}^{-1} \mathrm{~d}^{-1}$ ), nitrogen fixation (nmoles $\mathrm{N}^{-1} \mathrm{~d}^{-1}$ ), ammonium regeneration (nmoles $\mathrm{Nl}^{-1} \mathrm{~d}^{-1}$ ) and nitrification (nmoles $\mathrm{Nl}^{-1} \mathrm{~d}^{-1}$ ), along the BIOSOPE Transect. (Ocean Data View software (ODV), version 3.1; Reiner Schlitzer; http://odi.awi-bremerhaven.de/2005).

Surface light levels and the thickness of the euphotic layer were measured around noon using a spectroradiometer (LI.1800U.W, LI-COR instrument; Morel et al., 2007). The depth of the euphotic zone (Ze) was defined as the depth where the downward photosynthetical available radiation (PAR) irradiance was reduced to $1 \%$ of its surface value; For CTD casts performed early in the morning, Ze was computed using in situ TChl- $a$ concentration profiles (see Ras et al., 2007), according to the model developed by Morel and Maritorena (2001).

\section{Results}

A detailed description of the geographical distribution of nutrients and biomass during this study can be found in Raimbault et al. (2007). Briefly, the zonal distribution of surface nitrate showed minimal values (lower than the detection limit of 3 nmoles $1^{-1}$ ) between $125^{\circ} \mathrm{W}$ and $95^{\circ} \mathrm{W}$, i.e. in the South Pacific Gyre (SPG). Other regions (Marquesas Islands and Chilean upwelling) showed significant nitrate concentrations $\left(>0.5 \mu\right.$ moles $\left.^{-1}\right)$ in the surface. Chlorophyll biomass fol- lowed this general trend with very low values in the center of the SPG $\left(0.023 \mu \mathrm{gl}^{-1}\right)$, with levels reaching $0.3 \mu \mathrm{g}^{-1}$ near the Marquesas Islands and $1 \mu \mathrm{gl}^{-1}$ in the Chilean upwelling. The photic layer located at $40-50 \mathrm{~m}$ around the Marquesas and upwelling regions deepened in the centre of the SPG, reaching $160 \mathrm{~m}$ between $120^{\circ} \mathrm{W}$ and $105^{\circ} \mathrm{W}$, which could be expected in the clearest natural waters of the world (Morel et al., 2007; Tedetti et al., 2007). The incident solar radiation was more or less constant during the cruise $\left(41 \pm 7 \mathrm{Em}^{-2} \mathrm{~s}^{-1}\right)$ with the exception of three very cloudy days (9 to 11 November 2004 , e.g. from $120^{\circ} \mathrm{W}$ to $117^{\circ} \mathrm{W}$ ), where incident radiation decreased to $14-20 \mathrm{Em}^{-2} \mathrm{~s}^{-1}$.

Primary production and nitrogen uptake rates followed the same general distribution, responding to the nutrient variations observed in the photic layer along the transect (Fig. 4). A large central area was characterized by very low primary production rates and this was surrounded by two small regions: the subequatorial Marquesas region (in the west) where primary production reached $10 \mu \mathrm{g} \mathrm{Cl}^{-1} \mathrm{~d}^{-1}$ in surface waters, and a part of the Chilean upwelling in the east, which was the most productive area, primary 
production reaching more than $50 \mu \mathrm{gCl}^{-1} \mathrm{~d}^{-1}$. For the most part, the transect (e.g. the South Pacific Gyre $=$ SPG) was characterized by very low carbon fixation rates, less than $2 \mu \mathrm{g} \mathrm{Cl}{ }^{-1} \mathrm{~d}^{-1}$ between 130 and $95^{\circ} \mathrm{W}$. Vertical variations in primary production were insignificant in the centre of the SPG, with the rates remaining more or less constant $\left(\approx 1-2 \mu \mathrm{g} \mathrm{Cl}^{-1} \mathrm{~d}^{-1}\right)$ from the surface to the base of the photic layer. Nitrate and ammonium uptake rates followed the same general pattern as primary production. Nitrate uptake ranged from $100-500$ nmoles $1^{-1} \mathrm{~d}^{-1}$ in the upwelling to less than 5 nmoles $1^{-1} \mathrm{~d}^{-1}$ in the SPG. Intermediate values were found near the Marquesas Islands ranging from 20 and 100 nmoles $1^{-1} \mathrm{~d}^{-1}$. Ammonium uptake rates (corrected from isotopic dilution) were always significantly higher than nitrate uptake rates. The upwelling presented the highest uptake rates (up to $500 \mathrm{nmoles}^{-1} \mathrm{~d}^{-1}$ ), intermediate levels (up to 100 nmoles $\left.1^{-1} \mathrm{~d}^{-1}\right)$ were observed around the Marquesas Island and very low rates $\left(<40\right.$ nmoles $\left.1^{-1} \mathrm{~d}^{-1}\right)$ in the SPG As for primary production, vertical distribution of ammonium uptake, as well as nitrate uptake were quite homogeneous in the SPG, with very low vertical variation and no clear surface or subsurface maximum. However, contrary to primary production, noticeable rates of ammonium and nitrate uptake ( $>60$ and $>5$ nmoles $1^{-1} \mathrm{~d}^{-1}$, respectively) were detected, reaching depths of $100 \mathrm{~m}$ on the eastern edge of the SPG between 90 and $100^{\circ} \mathrm{W}$.

Dinitrogen fixation rates showed a particular distribution, with rates always lower than ammonium and nitrate uptake. Firstly, the vertical extension of this biological process was more important to the west (until $150 \mathrm{~m}$ ) than to the east of the investigated area. Secondly, nitrogen fixation was essentially located near the surface in the SPG, where a clear surface maximum $\left(>1\right.$ nmoles $\left.\mathrm{l}^{-1} \mathrm{~d}^{-1}\right)$ was detected. Rates decreased rapidly with depth and were $<0.5$ nmoles $1^{-1} \mathrm{~d}^{-1}$ below $50 \mathrm{~m}$. The geographical gradient was weak since maximum surface rates measured in the upwelling $\left(3.6\right.$ nmoles $\left.1^{-1} \mathrm{~d}^{-1}\right)$ were only two folds higher than the maximum rates measured in the SPG $\left(1.8\right.$ nmoles $\left.1^{-1} \mathrm{~d}^{-1}\right)$. The Marquesas Island was marked by intermediate nitrogen fixation $\left(\approx 2\right.$ nmoles $\left.1^{-1} \mathrm{~d}^{-1}\right)$.

Ammonium regeneration rates showed the same regional variations. This process was very active in surface water near the upwelling $\left(>200\right.$ nmoles $\left.1^{-1} \mathrm{~d}^{-1}\right)$, as well as around the Marquesas Islands with rates $>100$ nmoles $1^{-1} \mathrm{~d}^{-1}$ until $135^{\circ} \mathrm{W}$. Surface values decreased to $20 \mathrm{nmoles}^{-1} \mathrm{~d}^{-1}$ in the SPG, but remained more or less constant between the surface and $200 \mathrm{~m}$. As for ammonium uptake, a subsurface maximum (located around $125 \mathrm{~m}$ ) was detected on the eastern edge $\left(90^{\circ} \mathrm{W}\right)$ of the SPG. The significant ammonium regeneration measured at all stations, regardless of the trophic level, induced great variations of ammonium enrichment during the 24-h incubations. Figure 5 demonstrates that if isotopic dilution is not taken into account, then there is a massive underestimation of ammonium uptake of more than $50 \%$. Moreover, there was no relationship between the mag-

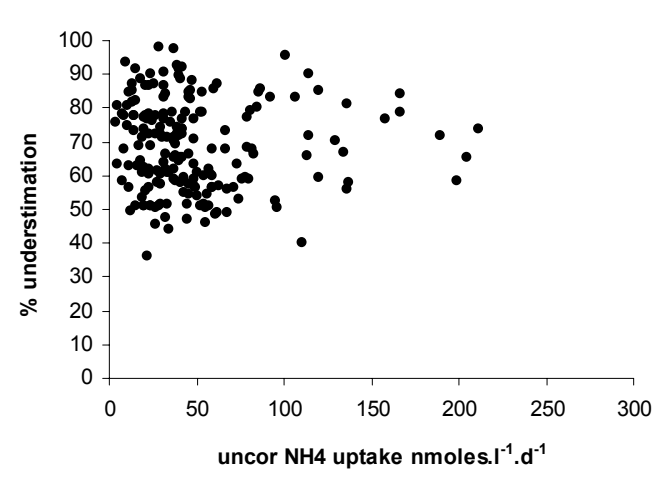

Fig. 5. Percentage of underestimation of ammonium uptake (\% underestimation) when isotopic dilution is not included for calculating rates versus ammonium uptake rates not corrected from the isotopic dilution (uncor $\mathrm{NH}_{4}$ uptake).

nitude of the underestimation and the uptake rates, clearly indicating that estimates of isotopic dilution are necessary in order to quantify ammonium uptake over 24-h incubations, even in oligotrophic waters.

Nitrification showed a similar pattern to that of ammonium regeneration, indicating a tight coupling between the two processes, although rates, always significant, were globally one order of magnitude lower than those of ammonium regeneration. Highest nitrification rates $\left(>30\right.$ nmoles $\left.^{-1} \mathrm{~d}^{-1}\right)$ were observed in the upwelling with a westward extension to $90^{\circ} \mathrm{W}$. The subsurface patch of ammonium regeneration at $90^{\circ} \mathrm{W}$ was also marked by active nitrification (up to 40 nmoles $1^{-1} \mathrm{~d}^{-1}$ ). The Marquesas region was characterized by relatively low nitrification rates (510 nmoles $\left.1^{-1} \mathrm{~d}^{-1}\right)$, while the lowest, but detectable values $\left(<5\right.$ nmoles $\left.1^{-1} \mathrm{~d}^{-1}\right)$ were measured in the SPG. As observed for preceding biological processes, nitrification was again homogeneous throughout the water column with no significant maximum in the oligotrophic central region. Nitrate uptake in comparison to nitrification generally dominated the upper layer, except in the SPG, where both rates were similar. At the base of the photic layer, nitrification rates were 2 to 10 times higher than the corresponding nitrate uptake rates, especially in the upwelling area.

A significant proportion of the ammonium was assimilated by the particulate matter passing through the GF/F filters (Fig. 6). This $<0.7 \mu \mathrm{m}$ ammonium uptake was significant in the upwelling region, with rates higher than 25 nmoles $1^{-1} \mathrm{~d}^{-1}$ and up to 170 nmoles $^{-1} \mathrm{~d}^{-1}$, but also significant in the SPG (10 to 20 nmoles $1^{-1} \mathrm{~d}^{-1}$ ). Some of the $<0.7 \mu \mathrm{m}$ uptake was ultimately found in the $<0.2 \mu \mathrm{m}$ fraction, i.e. in the dissolved organic nitrogen pool, rates here defined as $\rho_{\text {loss. }}$. Ammonium losses in terms of DON were again highest in the upwelling area (50 to 100 nmoles $\left.\mathrm{l}^{-1} \mathrm{~d}^{-1}\right)$, but highly significant in the oligotrophic SPG (5 to $20 \mathrm{nmoles}^{-1} \mathrm{~d}^{-1}$ ). The lowest rates $\left(<5\right.$ nmoles $\left.1^{-1} \mathrm{~d}^{-1}\right)$ were measured in the western part of 

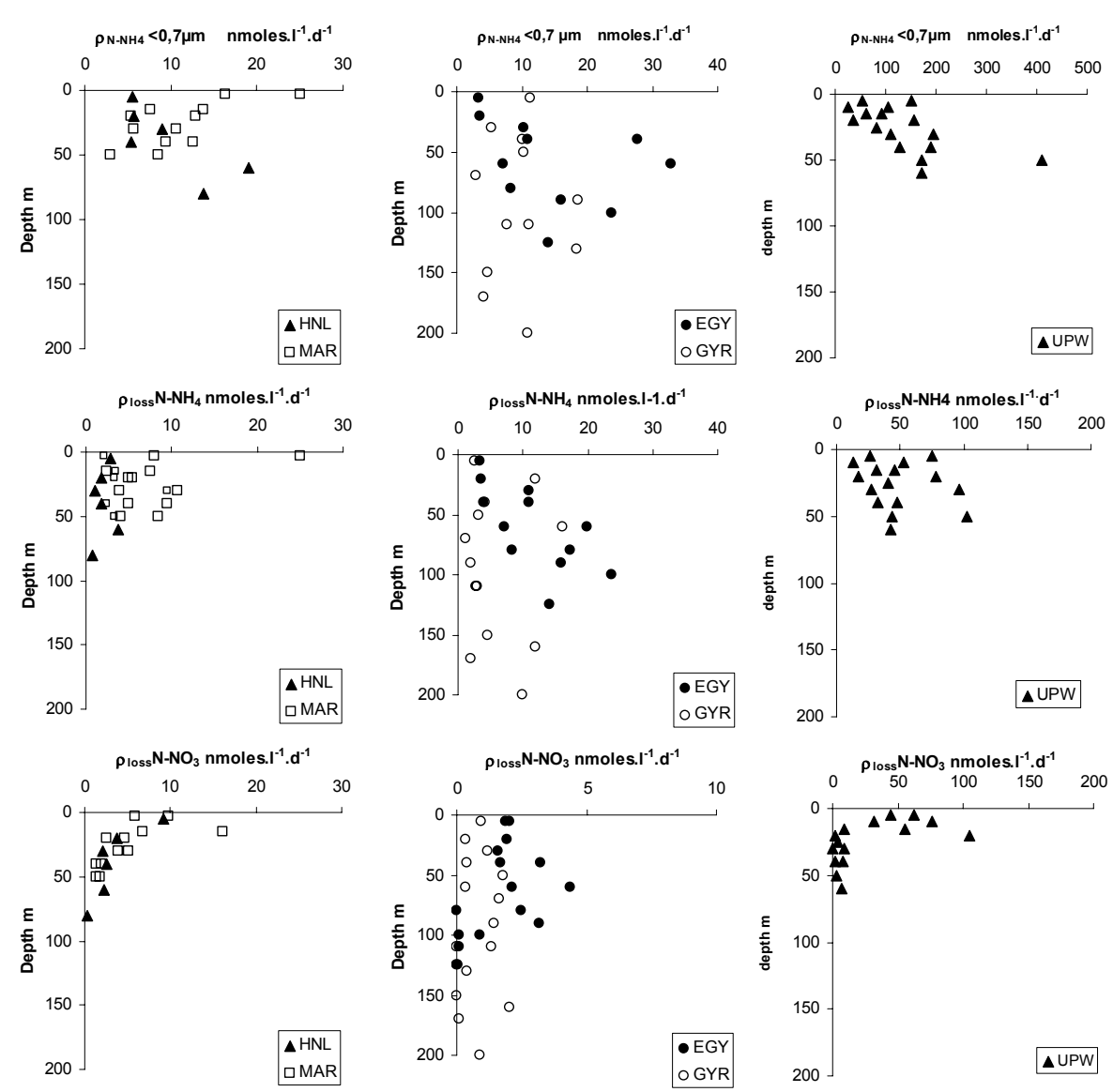

Fig. 6. Vertical profiles of ammonium uptake in the $<\mathrm{GF} / \mathrm{F}$ fraction $\left(\rho_{\mathrm{NH}_{4}}<0.7 \mu \mathrm{m}\right.$; upper panels), loss of ${ }^{15} \mathrm{~N}$-ammonium in terms of DON in the $<0.2 \mu \mathrm{m}$ fraction $\left(\rho_{\text {loss }} \mathrm{NH}_{4}\right.$; middle panels) and loss of ${ }^{15} \mathrm{~N}$-nitrate in terms of DON in the $<0.2 \mu \mathrm{m}$ fraction $\left(\rho_{\text {loss }} \mathrm{NO}_{3}\right.$; lower panels) at the five experimental sites.

the area. The nitrate losses were lowest in the SPG (1 to 5 nmoles $1^{-1} \mathrm{~d}^{-1}$ ) and highest in the surface waters of the upwelling. Some data in the SPG appeared close to zero and could be explained by the very low uptake rates of labeled nitrogen and then the very low excess enrichment in the $<0.2 \mu \mathrm{m}$ DON pool (close to $0.01 \%$ ). Loss of nitrate generally tended to decrease rapidly with depth, as observed in the most productive region (Marquesas Islands and Chilean upwelling). The mean DIN percentage loss showed important regional variations (Table 1). The lowest productive system (SPG) revealed the most important loss of recent nitrogen uptake ( $>20 \%$ ), while in the other regions percentage losses were less than $15 \%$. It should be noted that the percentage of $\mathrm{N}$-nitrate losses were equivalent to those of $\mathrm{N}$-ammonium losses, except around the Marquesas Islands (Mar and HLN sites).

Several corrections have been applied to the f-ratio to take into account several processes that are rarely measured during nitrogen uptake experiments, such as nitrification, DIN loss and nitrogen fixation. Nitrification (as a source of nitrate) can induce overestimations of new production by adding $\mathrm{NO}_{3}^{-}$to the nitrate pool, with some being derived from regenerated production (Dore and Karl, 1996; Ward et al., 1989; Priscu and Downes, 1985; Dugdale and Goering, 1967). Thus, the fraction of nitrate produced by nitrification $\left(\rho_{\mathrm{NIT}}\right)$ has to be subtracted from the total nitrate uptake $\left(\rho_{\mathrm{NO}_{3}}\right)$ in order to truly assess the uptake of "new" nitrate as classically defined by Dugdale and Goering (1967). As nitrogen fixation rates $\left(\rho_{\mathrm{N}_{2}}\right)$ were available, they were included in the estimate of new production $\left(P_{\text {new }}\right)$, calculated as follows:

$P_{\text {new }}=\rho_{\mathrm{N}_{2}}+\left(\rho_{\mathrm{NO}_{3}}-\rho_{\mathrm{NIT}}\right)$.

When nitrification rates were higher than nitrate uptake $\left(\rho_{\mathrm{NO}_{3}}-\rho_{\mathrm{NIT}<0}\right), P_{\text {new }}$ was estimated to be equal to $\rho_{\mathrm{N}_{2}}$. According to this assumption, the f-ratio can be calculated as follows:

$f=\frac{\rho_{\mathrm{N}_{2}}+\rho_{\left(\mathrm{NO}_{3}^{-}\right)}-\rho_{\mathrm{NIT}}}{\left[\rho_{\mathrm{N}_{2}}+\rho_{\left(\mathrm{NO}_{3}^{-}\right)}+\rho_{\left(\mathrm{NH}_{4}^{+}\right)}\right]}$.

As $\rho_{\text {loss }}$ was not available for all stations (especially from ${ }^{15} \mathrm{~N}^{-\mathrm{NO}_{3}}$ experiments), gross uptake rates were not used in the calculation of the f-ratio, which was only estimated with 
Table 1. Percentages (mean values integrated over the photic layer) of ammonium uptake in the $<\mathrm{GF} / \mathrm{F}$ filtrate $\left(\rho_{<0.7 \mu \mathrm{m}}\right)$ and loss in terms of DON $\left(\rho_{\mathrm{DON}}<0.2 \mu \mathrm{m}\right)$ from ammonium and nitrate relative to gross uptake rates $\left(\rho_{\text {gross }}=\rho_{\text {net }}+\rho_{\text {DON }}<0.2 \mu \mathrm{m}\right)$ for the five investigated oceanic regions. Values from nitrate values are available from only in situ profiles performed on the 5 experimental sites.

\begin{tabular}{|c|c|c|c|c|c|c|}
\hline \multirow[b]{2}{*}{ Area } & \multicolumn{2}{|c|}{$\begin{array}{l}\text { Ammonium } \\
\% \rho_{\text {gross }}\end{array}$} & & \multicolumn{2}{|c|}{$\begin{array}{l}\text { Ammonium } \\
\% \rho_{\text {gross }}\end{array}$} & \multirow{2}{*}{$\begin{array}{c}\text { Nitrate } \\
\% \rho_{\text {gross }} \\
\rho_{\text {DON }<0.2 \mu \mathrm{m}}\end{array}$} \\
\hline & $\rho<0.7 \mu \mathrm{m}$ & $\rho_{\mathrm{DON}}<0.2 \mu \mathrm{m}$ & Experimental site & $\rho<0.7 \mu \mathrm{m}$ & $\rho_{\mathrm{DON}}<0.2 \mu \mathrm{m}$ & \\
\hline $\operatorname{MAR}\left(141^{\circ}-134^{\circ} \mathrm{W}\right)$ & $7 \pm 4$ & $4 \pm 2$ & $12^{\circ} \mathrm{S}-138^{\circ} \mathrm{W}$ & $6 \pm 3$ & $4 \pm 2$ & $11 \pm 4$ \\
\hline $\operatorname{HNL}\left(133^{\circ}-123^{\circ} \mathrm{W}\right)$ & $17 \pm 14$ & $10 \pm 9$ & $9^{\circ} \mathrm{S}-136^{\circ} \mathrm{W}$ & $7 \pm 4$ & $1 \pm 1$ & $10 \pm 7$ \\
\hline $\operatorname{SPG}\left(123^{\circ}-101^{\circ} \mathrm{W}\right)$ & $41 \pm 19$ & $28 \pm 13$ & $26^{\circ} \mathrm{S}-114^{\circ} \mathrm{W}$ & $26 \pm 14$ & $20 \pm 7$ & $19 \pm 12$ \\
\hline $\mathrm{EGY}\left(100^{\circ}-81^{\circ} \mathrm{W}\right)$ & $25 \pm 15$ & $15 \pm 13$ & $32^{\circ} \mathrm{S}-91^{\circ} \mathrm{W}$ & $16 \pm 14$ & $12 \pm 7$ & $11 \pm 9$ \\
\hline $\mathrm{UPW}\left(80^{\circ}-72^{\circ} \mathrm{W}\right)$ & $26 \pm 36$ & $12 \pm 9$ & $34^{\circ} \mathrm{S}-73^{\circ} \mathrm{W}$ & $55 \pm 61$ & $16 \pm 14$ & $12 \pm 8$ \\
\hline
\end{tabular}

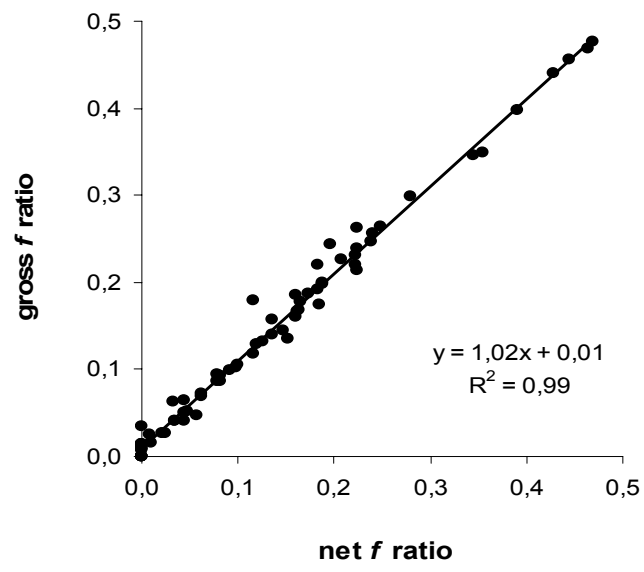

Fig. 7. Comparison of f-ratio calculating from gross nitrogen uptake (gross f-ratio) and from net nitrogen uptake rates (net f-ratio). The linear regression line was obtained from model II regression.

the net uptake rates. Using data from in situ experiments, where both losses of $\mathrm{N}$-nitrate and $\mathrm{N}$-ammonium were measured, the model II regression analysis gives a slope of 1.02 (Fig. 7). The slope was not significantly different from 1, indicating that by including DIN loss one does not change the estimates of the f-ratios. To assess the influence of nitrification and $\mathrm{N}_{2}$-fixation on the magnitude of the f-ratio, we compared the f-ratio calculation, according to Eq. (5), to those calculated without nitrification $\left(f_{-\mathrm{NIT}}\right)$ or without $\mathrm{N}_{2}$-fixation $\left(f_{-\mathrm{N}_{2}}\right)$. The possible overestimation due to the noninclusion of uptake of urea could not be evaluated, since fluxes of this organic nitrogen compound have not been investigated in this area.

The geographical variations of the f-ratios (averaged over the photic layer) reflect the zonal evolution of the trophic states (Fig. 8), with highest values $(>0.30)$ observed in the upwelling. Waters surrounding the Marquesas Islands were characterized by f-ratios ranging between 0.1 and 0.2 . In the SPG, the f-ratio was generally lower than 0.1 , with very low

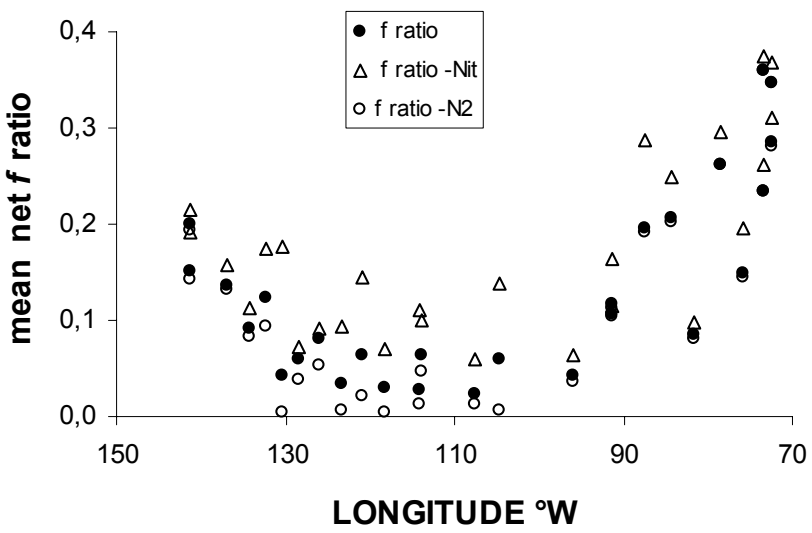

Fig. 8. Zonal evolution of net f-ratio calculating without nitrification (f-ratio - Nit), without dinitrogen fixation (f-ratio $-\mathrm{N}_{2}$ ), or including both processes (f-ratio).

values (0.02) found in the centre. The exclusion of nitrification rates $\left(f_{-\mathrm{NIT}}\right)$ significantly increased the $\mathrm{f}$-values in the SPG (0.08-0.15). In the other regions nitrification, although acting at significant rates, did not modify the mean f-ratio. In the same way, the influence of nitrogen fixation was only sensitive in the SPG. In this oligotrophic area, $f_{-\mathrm{N}_{2}}$ down to very low values (often close to 0 ) clearly indicated that nitrogen fixation was the main process providing new nitrogen in this upper layer.

\section{Discussion}

This study confirms previous satellite observations suggesting very low productivity in the SPG, i.e. in the clearest waters of the world's ocean (Morel et al., 2007; Tedetti et al., 2007). Nixon (1995) assigned annual rates of carbon fixation of $<100,100$ to 300 and 300 to $500 \mathrm{~g} \mathrm{C} \mathrm{m}^{-2} \mathrm{y}^{-1}$ in oligotrophic, mesotrophic and eutrophic areas, respectively. Following this criterion and assuming that our measured rates remained constant over the year, the upwelling 
Table 2. Mean and standard deviation of integrated rates over the photic layer of nitrate $\left(\Sigma \mathrm{NO}_{3}\right)$, primary production ( $\left.\Sigma \mathrm{PP}\right)$, nitrate uptake $\left(\Sigma \rho_{\mathrm{NO}_{3}}\right)$, ammonium uptake $\left(\Sigma \rho_{\mathrm{NH}_{4}}\right)$, nitrogen fixation $\left(\Sigma \rho_{\mathrm{N}_{2}}\right)$, carbon/nitrogen ratio during uptake $(\mathrm{C} / \mathrm{N})$, ammonium regeneration $\left(r \mathrm{NH}_{4}\right)$ and nitrification $\left(\rho_{\mathrm{NIT}}\right)$ pooled for each studied oceanic area.

\begin{tabular}{|c|c|c|c|c|c|c|c|c|c|}
\hline Area & $\begin{array}{c}\Sigma \mathrm{NO}_{3} \\
\text { mmoles m }^{-2}\end{array}$ & $\begin{array}{c}\Sigma \mathrm{PP} \\
\mathrm{g} \mathrm{m}^{-2} \mathrm{~d}^{-1}\end{array}$ & $\Sigma \rho_{\mathrm{NO}_{3}}$ & $\begin{array}{l}\sum \rho_{\mathrm{NH}_{4}} \\
\text { holes m }\end{array}$ & $\Sigma \rho_{\mathrm{N}_{2}}$ & ${ }_{\mathrm{ml}}^{\mathrm{C} / \mathrm{N}}$ & $\begin{array}{l}\Sigma \rho_{\mathrm{NH}_{4}} \\
\text { les m } \\
-2\end{array}$ & $\sum r_{\mathrm{NH}_{4}}$ & $\Sigma \rho_{\mathrm{NIT}}$ \\
\hline $\operatorname{MAR}\left(141^{\circ}-134^{\circ} \mathrm{W}\right)$ & $128 \pm 24$ & $0.66 \pm 0.1$ & $2.2 \pm 1.1$ & $8.7 \pm 3.6$ & $0.11 \pm 0.03$ & $6.3 \pm 2.6$ & $6.3 \pm 1.6$ & $5.8 \pm 1.9$ & $0.82 \pm 0.4$ \\
\hline $\operatorname{HNL}\left(133^{\circ}-123^{\circ} \mathrm{W}\right)$ & $49 \pm 73$ & $0.25 \pm 0.12$ & $0.5 \pm 0.7$ & $4.6 \pm 4.3$ & $0.07 \pm 0.07$ & $5.2 \pm 2.2$ & $2.6 \pm 0.8$ & $4.8 \pm 3.1$ & $0.61 \pm 0.7$ \\
\hline $\operatorname{SPG}\left(123^{\circ}-101^{\circ} \mathrm{W}\right)$ & $0.84 \pm 1.3$ & $0.15 \pm 0.05$ & $0.06 \pm 0.06$ & $2.1 \pm 1.0$ & $0.06 \pm 0.03$ & $6.1 \pm 2.3$ & $1.2 \pm 0.6$ & $3.5 \pm 1.9$ & $0.76 \pm 0.4$ \\
\hline $\operatorname{EGY}\left(100^{\circ}-81^{\circ} \mathrm{W}\right)$ & $141 \pm 67$ & $0.33 \pm 0.6$ & $0.82 \pm 0.4$ & $6.0 \pm 2.3$ & $0.03 \pm 0.005$ & $4.4 \pm 1.4$ & $2.9 \pm 0.4$ & $6.3 \pm 2.0$ & $0.81 \pm 0.5$ \\
\hline $\mathrm{UPW}\left(80^{\circ}-72^{\circ} \mathrm{W}\right)$ & $285 \pm 310$ & $1.8 \pm 1.3$ & $8.6 \pm 6.8$ & $20 \pm 10$ & $0.09 \pm 0.06$ & $4.9 \pm 0.9$ & $6.2 \pm 2.0$ & 1911 & $1.31 \pm 06$ \\
\hline
\end{tabular}

$\left(660 \mathrm{~g} \mathrm{C} \mathrm{m}^{-2} \mathrm{y}^{-1}\right)$ could be described as eutrophic, the Marquesas region as mesotrophic $\left(270 \mathrm{~g} \mathrm{C} \mathrm{m}^{-2} \mathrm{y}^{-1}\right)$, and the SPG $\left(36 \mathrm{~g} \mathrm{C} \mathrm{m}^{-2} \mathrm{y}^{-1}\right)$ as an "ultra" oligotrophic system.

The zonal variation of integrated rates over the euphotic layer, using the trapezoidal method, revealed some specific patterns (Table 2). For example, the increase in primary production and nitrogen uptake was not as pronounced as the increase in nutrient availability. Although integrated nitrate concentrations increased by a factor of 100 and 300 from the oligotrophic zone $\left(0.9 \mathrm{mmoles} \mathrm{m}^{-2}\right)$ to the Marquesas or to upwelling regions $\left(128 \mathrm{mmoles} \mathrm{m}^{-2}\right.$ and up to $285 \mathrm{mmoles} \mathrm{m}^{-2}$, respectively), integrated carbon fixation rates increased only by 10 to 20 fold. Nitrogen fixation appeared more or less constant around $0.03-0.11$ mmoles $^{-2} \mathrm{~d}^{-1}$, while integrated nitrate uptake increased 10 or 50 fold between the SPG $\left(0.2\right.$ mmoles $\left.\mathrm{m}^{-2} \mathrm{~d}^{-1}\right)$ and the Marquesas region $\left(2.9\right.$ mmoles $\left.\mathrm{m}^{-2} \mathrm{~d}^{-1}\right)$ or the upwelling $\left(11 \mathrm{mmoles}^{-2} \mathrm{~d}^{-1}\right)$. The $\mathrm{C} / \mathrm{N}$ uptake ratios were always lower than the conventional 6.6 Redfield ratio (Table 2). Such low $\mathrm{C} / \mathrm{N}$ uptake ratios may suggest that some nitrogen assimilation (especially ammonium) was due to heterotrophic organisms. The importance of submicron heterotrophic organisms was emphasized by the large quantity of ${ }^{15} \mathrm{~N}-\mathrm{NH}_{4}$ found in the $<\mathrm{GF} / \mathrm{F}$ filtrates, i.e. the $<0.7 \mu \mathrm{m}$ size fraction, following 24-h incubations (Table 1). The low efficiency of the GF/F filters for PON retention compared to $0.2-\mu \mathrm{m}$ membranes is now well-documented in a variety of marine environments (Altabet, 1990; Libby and Wheeler, 1997; Slawyk and Raimbault, 1995; Raimbault et al., 2000; Fernandez et al., 2007) and has been confirmed during this study (Raimbault et al., 2007). Our experiments showed that the use of GF/F filters can result in severe underestimations of ammonium uptake during high productivity, as well as under oligotrophic conditions. This emphasizes the importance of discussing the use of GF/F and $0.2-\mu \mathrm{m}$ filters for tracer addition experiments. GF/F filters do, however, collect all particles containing chlorophyll, i.e photosynthetic organisms (Chavez et al., 1995; Raimbault et al., 2007) and this heterotrophic ammonium uptake should not be included in the estimates for regenerated primary production. Con- sequently, the underestimation of gross ammonium uptake rates by filtering through GF/F filters should not have any consequences for the f-ratio estimation. There are no current data available giving information on the possible nitrate uptake by the $<0.7 \mu \mathrm{m}$ size fraction; however, a study conducted in the equatorial Pacific has shown that submicron particles passing through the GF/F filters do not assimilate nitrate (Raimbault et al., 2000).

As our $\mathrm{C} / \mathrm{N}$ uptakes deviate from the Redfield ratio, no relationship was found between new production estimates obtained using the ${ }^{13} \mathrm{C}$ fixation rates, multiplied by the independently estimated f-ratio, and those computed using direct measurements of new nitrogen multiplied by the 6.6 Redfield ratio (Table 3). The two estimates often disagreed by $25-$ $50 \%$, with the lowest $\left(0.007-0.008 \mathrm{~g} \mathrm{C} \mathrm{m}^{-2} \mathrm{~d}^{-1}\right)$ and highest $\left(0.53-0.69 \mathrm{~g} \mathrm{C} \mathrm{m}^{-2} \mathrm{~d}^{-1}\right)$ values found in the SPG and in the upwelling, respectively. The extremely low f-ratio obtained in the SPG $(0.05 \pm 0.03)$ confirms that most of the primary production, which maintained relatively significant rates over the $0-180 \mathrm{~m}$ water column, was supported by regenerated nitrogen. This is indicated by the relatively high values of ammonium uptake $\left(2.1\right.$ mmoles $\left.\mathrm{m}^{-2} \mathrm{~d}^{-1}\right)$, as well as by significant ammonium and nitrate regeneration rates, 3.5 and 0.76 mmoles $^{-2} \mathrm{~d}^{-1}$, respectively (Table 2). Rates of $\mathrm{NH}_{4}$ regeneration are rare for oceanic waters but our results are in the range of the data available (e.g. Bode et al., 2002; Raimbault et al., 1999; Fernandez and Raimbault, 2007). Ammonium regeneration showed high rates (up to 500 nmoles $1^{-1} \mathrm{~d}^{-1}$ ) in the high productive Marquesas and upwelling regions (MAR and UPW), but significant activity was also measured in the SPG $\left(10-20\right.$ nmoles $\left.\mathrm{l}^{-1} \mathrm{~d}^{-1}\right)$; these rates were able to sustain the biological demand. This observation was substantiated by the picoplankton abundance which was strongly dominated by heterotrophic bacterioplankton along the whole transect (Grob et al., 2007).

Another important finding was the magnitude of the nitrification process in the euphotic layer. Although the potential significance of "regenerated" nitrate in the euphotic zone has been acknowledged for some time (Dugdale and Goering, 1967; Ward et al., 1989; Dore and Karl, 1996) and nitrification studies have been performed in a variety 
Table 3. Mean and standard deviation of integrated rates over the photic layer of chlorophyll- $a$ ( $\Sigma T$ chlo), f-ratio calculated with net uptake rates of dissolved inorganic nitrogen $\left(f_{\text {net }}\right)$, new production calculated by multiplied rates of dissolved inorganic nitrogen rates by the Redfield ratio 6.6 (New $\mathrm{PP}$ ) or by multiplying the primary production by the f-ratio $(\mathrm{PP} \times f)$ for the five investigated oceanic regions. Mean "net f-ratio" $\left(f_{\text {net }}\right)$ and "gross f-ratio" ( $\left.f_{\text {gross }}\right)$ are compared with data obtained during in situ experiments performed at 5 experimental sites.

\begin{tabular}{lccccccc}
\hline Area & $\begin{array}{c}T \text { chlo } \\
\mathrm{mg} \mathrm{m}^{-2}\end{array}$ & $\begin{array}{c}f_{\text {net }} \\
\text { mean }\end{array}$ & $\begin{array}{c}\text { New PP } \\
\mathrm{g} \mathrm{C} \mathrm{m}^{-2} \mathrm{~d}^{-1}\end{array}$ & $\begin{array}{c}\mathrm{PP} \times f \\
\mathrm{~g} \mathrm{C} \mathrm{m}^{-2} \mathrm{~d}^{-1}\end{array}$ & $\begin{array}{c}f_{\text {net }} \\
\text { experimental sites }\end{array}$ & $f_{\text {gross }}$ \\
\hline MAR $\left(141^{\circ}-134^{\circ} \mathrm{W}\right)$ & $27 \pm 5$ & $0.18 \pm 0.04$ & $0.18 \pm 0.10$ & $0.13 \pm 0.02$ & $12^{\circ} \mathrm{S}-138^{\circ} \mathrm{W}$ & 0.18 & 0.19 \\
$\mathrm{HNL}\left(133^{\circ}-123^{\circ} \mathrm{W}\right)$ & $18 \pm 4$ & $0.08 \pm 0.04$ & $0.04 \pm 0.06$ & $0.02 \pm 0.02$ & $9^{\circ} \mathrm{S}-136^{\circ} \mathrm{W}$ & 0.09 & 0.10 \\
SPG $\left(123^{\circ}-101^{\circ} \mathrm{W}\right)$ & $11 \pm 2$ & $0.05 \pm 0.03$ & $0.008 \pm 0.007$ & $0.007 \pm 0.007$ & $26^{\circ} \mathrm{S}-114^{\circ} \mathrm{W}$ & 0.05 & 0.06 \\
EGY $\left(100^{\circ}-81^{\circ} \mathrm{W}\right)$ & $16 \pm 4$ & $0.12 \pm 0.07$ & $0.07 \pm 0.03$ & $0.04 \pm 0.03$ & $32^{\circ} \mathrm{S}-91^{\circ} \mathrm{W}$ & 0.11 & 0.11 \\
UPW $\left(80^{\circ}-72^{\circ} \mathrm{W}\right)$ & $44 \pm 28$ & $0.27 \pm 0.08$ & $0.69 \pm 0.49$ & $0.53 \pm 0.47$ & $34^{\circ} \mathrm{S}-73^{\circ} \mathrm{W}$ & 0.27 & 0.28 \\
\hline
\end{tabular}

of marine environments (Ward et al., 1984; Codispoti and Christensen, 1985; Ward and Zafiriou, 1988), observations in the open ocean are rare (Lomas and Lipschultz, 2006). Nitrification rates presented here (Table 2) are in the range of previous observations (e.g. Ward and Zafiriou, 1988; Bianchi et al., 1994; Raimbault et al., 1999; Fernandez and Raimbault, 2007). Regeneration processes were active throughout the water column, even in the oligotrophic waters of the SPG and were largely able to sustain the phytoplanktonic demand in the photic layer (Table 2). Rates measured in the top $100 \mathrm{~m}$ suggest that about 80 to $100 \%$ of nitrate uptake in the surface waters was supported by nitrification in the SPG. This result confirms the significant role of nitrification in the upper layers of oceanic waters, as previously reported in the equatorial Pacific, where 20 to $100 \%$ of the total nitrate demand was fueled by nitrification (Raimbault et al., 1999) and 142\% at station ALOHA (Dore and Karl, 1996). The role of nitrification in providing regenerated nitrate in the euphotic zone has been confirmed by recent findings in the Atlantic, as well as in the Mediterranean Sea, where nitrification can support 25 to $100 \%$ of the new production (Diaz and Raimbault, 2000; Fernandez and Raimbault, 2007). A logical conclusion is that there could be overestimations in new production data when all the nitrogen regeneration processes are not taken into account. In terms of integrated values over the photic layer, overestimation was only significant in the SPG, where rates of new nitrate assimilation were lower than expected, even close to zero. Consequently, average f-ratio values were very low in the SPG but there were no zero values since significant new production was sustained by $\mathrm{N}_{2}$-fixation, which appeared as the only source of new nitrogen in the upper layer of the SPG (Fig. 8).

Along the investigated area, primary production remained quantitatively related to new production (Fig. 9), revealing that a threefold increase in total production in oligotrophic waters would result in a tenfold increase of new production. Such a relationship between primary production and new production corresponds with the data of Dugdale et al. (1992) and Raimbault et al. (1999) for the equatorial Pacific (until $16^{\circ} \mathrm{S}$ ), but were much lower (up to 10 fold) than those esti-

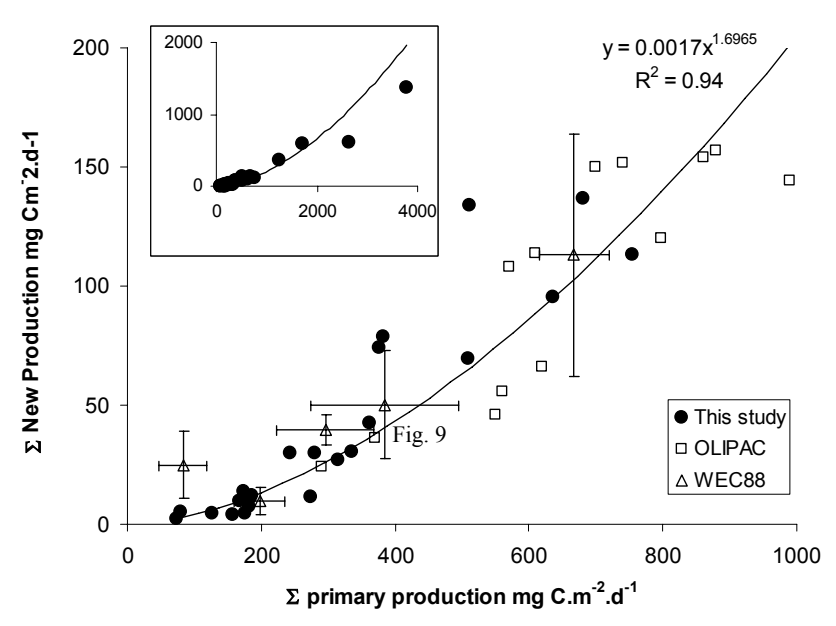

Fig. 9. Plot of integrated new production ( $\Sigma$ New production) versus integrated primary production ( $\Sigma$ primary production). OLIPAC data are from Raimbault et al. (1999); WEC 88 data are from Dugdale et al. (1992). The power relationship is calculated from data of this study (dark points). Insert shows present data for primary production higher than $1000 \mathrm{mg} \mathrm{C} \mathrm{m}^{-2} \mathrm{~d}^{-1}$.

mated by the model of Eppley and Peterson (1979). Moreover, in this very oligotrophic water, exhibiting strong nutrient gradients, there was no evident pattern between nitrate concentration and new production, as suggested by Platt and Harrison (1985). When mean f-ratio values are plotted against integrated primary productivity values there is a positive relationship (Fig. 10). The initial linearly slope (0.0003) for new production $<500 \mathrm{mg} \mathrm{m}^{-2} \mathrm{~d}^{-1}\left(\approx 200 \mathrm{mg} \mathrm{m}^{-2} \mathrm{y}^{-1}\right)$ is close to that of Dugdale et al. (1992) for the equatorial Pacific (0.00063 \pm 0.00036$)$, but much lower than the 0.0025 proposed by Eppley and Peterson (1979). The model proposed by Eppley and Peterson (1979) does not work in these oceanic waters, as nitrate uptake in coastal regions is very different from that in oligotrophic waters.

The f-ratio provides an indirect estimation of export rates of particulate organic matter toward the deep ocean only when suitable time scales are considered. This concept is 


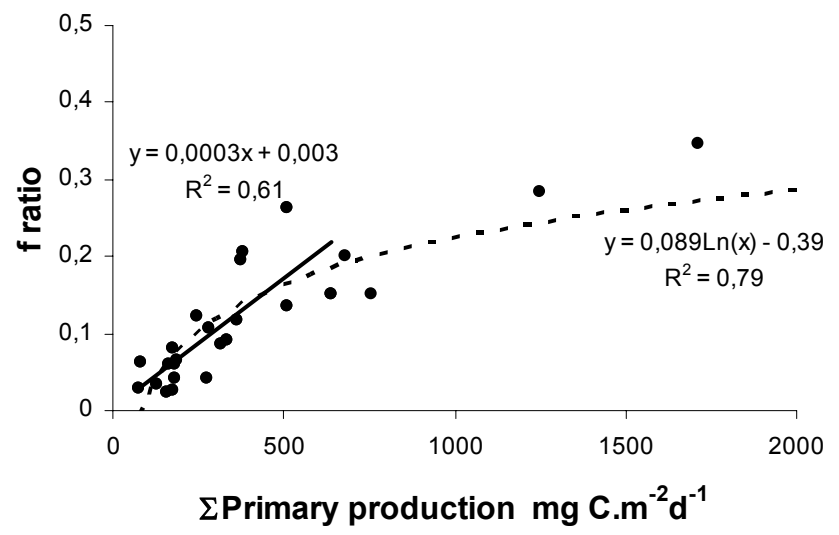

Fig. 10. Plot of mean f-ratio (f-ratio) versus integrated primary production ( $\Sigma$ primary production). Dashed curve is the best relationship calculated for all the data. Straight line is the linear relationship calculated for primary production lower than $500 \mathrm{mg} \mathrm{C} \mathrm{m}^{-2} \mathrm{~d}^{-1}$.

supported by the assumption that the input by advection and diffusion of nitrate towards the surface should be balanced by the losses of particulate and dissolved matter to the deep sea. Sinking fluxes of POC $\left(0.14-1.15 \mathrm{mg} \mathrm{C} \mathrm{m}^{-2} \mathrm{~d}^{-1}\right)$ and PON $\left(0.04-0.2 \mathrm{mg} \mathrm{N} \mathrm{m}^{-2} \mathrm{~d}^{-1}\right)$ measured in the SPG by sediment traps (J. C. Miquel, personal communication) appear to be much lower than the new production rates obtained using tracer uptake experiments $\left(7-8 \mathrm{mg} \mathrm{C} \mathrm{m}^{-2} \mathrm{~d}^{-1}\right.$; $1.7 \mathrm{mg} \mathrm{N} \mathrm{m}^{-2} \mathrm{~d}^{-1}$ ). There are several reasons to explain this discrepancy. The main one is the export of dissolved organic matter (by vertical mixing or horizontal advection) which can exceed fluxes of sinking particles and thus appear as the major fate of new production (Copin-Montégut-and Avril, 1993; Peltzer and Hayward, 1996). According to Toggweiler (1989), the most realistic balance is obtained when half of the new production sustained by upwelled nutrients goes into a pool of dissolved organic compounds. In fact, our data demonstrated that a significant part of the DIN taken up was lost as dissolved organic nitrogen (DON) during the 24-h incubation experiments. It is difficult to ascertain whether the ${ }^{15} \mathrm{~N}$-tracer detected in the DON pool was transferred solely by the direct and active release from living phytoplankton cells. The ${ }^{15} \mathrm{~N}$ excess enrichment in the DON pool may have resulted from cell rupture, by sloppy-feeding, and from cell analysis due to viral infection (Bronk et al., 1994; Procter and Fuhrman, 1990). Pooling all available data, $\mathrm{DI}^{15} \mathrm{~N}$ ultimately found in the extracellular DON pool ( $\left.\rho_{\text {loss }}\right)$ represented, on average, 13 to $15 \%$ of the nitrate and ammonium, respectively. Values were often higher in the SPG, up to $46 \%$ in the subsurface layer. It appears that the $\rho_{\text {net }}: \rho_{\text {gross }}$ ratios were in the range of values found in literature, i.e. between the low loss rates $(<15 \%)$ found in the equatorial Pacific (Raimbault et al., 1999, 2000) and the very high ones $(74 \%)$ found in the Southern California Bight by Bronk and Glibert (1991). They are also in the same order of magnitude as those found in the Mediterranean Sea during spring (Diaz and Raimbault, 2000) and in the Atlantic Ocean (Fernandez and Raimbault, 2007).

However, one should keep in mind that $\rho_{\text {loss }}$ does not represent the total flux of nitrogen from the particulate organic matter (PON) in the DON pool (Slawyk et al., 2000). The true DON release $\left(\rho_{\mathrm{DON}}\right)$ is greater than our measured loss of DIN ( $\left.\rho_{\text {loss }}\right)$. Quantification of $\rho_{\text {DON }}$ depends on the ${ }^{15} \mathrm{~N}$ enrichment in the intracellular DON $\left(R_{\mathrm{DON} i}\right) . R_{\mathrm{DON} i}$ is not experimentally accessible, but it is related to the initial ${ }^{15} \mathrm{~N}$ enrichment DIN pool $\left(R_{\mathrm{DIN}}\right)$, according the relationship defined by Raimbault et al. (2000),

$\rho_{\mathrm{DON}}=\rho_{\mathrm{loss}} \times R_{\mathrm{DIN}} / R_{\mathrm{DON} i}$.

Due to of the dilution of the ${ }^{15} \mathrm{~N}$ tracer by intracellular nitrogen during uptake, $R_{\mathrm{DIN}} / R_{\mathrm{DON} i}$ is greater than 1 . This relationship indicates that; 1) the total fluxes of organic nitrogen from particulate matter to extracellular DON would be higher than the loss of tracer in the form of DON, as measured here and 2) the lower the final enrichment of the intracellular DON pool, the greater the difference between DIN loss and DON release. Assuming phytoplanktonic growth rates calculated from the residence time of chlorophyll-containing particles (Raimbault et al., 2007), the $R_{\mathrm{DIN}} / R_{\mathrm{DON} i}$ ratio would be 3 to 6 folds higher in the SPG than in the productive regions (Marquesas Islands and Chilean upwelling). Consequently, we can hypothesize that production of DON was proportionally much higher in the oligotrophic waters than in productive systems, and consequently, this process could be a significant way for export production in the SPG.

The availability of high-precision isotope ratio mass spectrometers, combined with sensitive field tracer methods (Montoya et al., 1996) enable ${ }^{15} \mathrm{~N}_{2}$-tracer incubations to be carried out on unconcentrated natural water samples, with minimal disturbance of the system. However, measurements of $\mathrm{N}_{2}$-fixation in oceanic waters are rare and the data reported here are the first available for the South Pacific. The iron supply from atmospheric dust deposition at the sea surface has been hypothesized to favour $\mathrm{N}_{2}$-fixation in the areas influenced by the continents, e.g. the Atlantic Ocean. $\mathrm{N}_{2}$ fixation, due to high phosphorus requirements, could lead to a decrease in the soluble reactive phosphorus until a shift from $\mathrm{N}$ to $\mathrm{P}$ limitation occurs, as hypothesized by Béthoux and Copin-Montégut (1986) and Karl et al. (2002) for the Mediterranean Sea and the North Pacific Oceanic, respectively. Elevated $\mathrm{N}$ to $\mathrm{P}$ in the dissolved inorganic is often considered as indicative of $\mathrm{N}_{2}$ fixation (Grüber and Sarmiento, 1997). From this point of view, the waters of the South Pacific, characterized by very low dust depositions (Mahowald et al., 1999) and by having sufficient phosphorus concentrations and very low nitrate/phosphate ratios (Raimbault et al., 2007) do not seem to be favourable regions for $\mathrm{N}_{2}$-fixers. Nevertheless, significant rates were measured throughout the transect, confirming results from recent work using ocean 
circulation modelling (Deutsch et al., 2007). $\mathrm{N}_{2}$-fixation was the weakest, but the most stable biological process along the $8000-\mathrm{km}$ investigated area, in spite of large deviations in nutrient biomass and primary productivity. In the SPG, $\mathrm{N}_{2}$ fixation $\left(0.06\right.$ mmoles $\left.\mathrm{m}^{-2} \mathrm{~d}^{-1}\right)$ was essentially located in the upper layer $(0-50 \mathrm{~m})$, where irradiance was higher and atmospheric deposition, even though very weak in this region, was more readily available. The highest $\mathrm{N}_{2}$-fixation rates $\left(0.09-0.11 \mathrm{mmoles} \mathrm{m}^{-2} \mathrm{~d}^{-1}\right)$ were observed around the Marquesas Islands and in the Chilean upwelling (Table 2). The most surprising feature was the high $\mathrm{N}_{2}$-fixation rates found in the cold and nutrient-replete waters along the Chilean coast, since nitrogen fixation is commonly associated with certain cyanobacteria, essentially Trichodesmium sp., that inhabit the warm and nutrient-depleted subtropical waters (Capone et al., 2005; Mahaffey et al., 2005). But this observation confirms the result of Deutsch et al.'s model (2007) that provides evidence that biological fixation could also be intimately linked with marine nitrogen removal in the South Pacific Ocean.

Unfortunately, the organisms responsible for this process were not identified in this study. The organisms responsible for $\mathrm{N}_{2}$ fixation are taxonomically, physiologically, and ecologically diverse, including bacteria (phototrophs, heterotrophs, chemolithotophs) heterocystous and nonheterocystous cyanobacteria and Archeae (Karl et al., 2002). But much of the oceanic research about $\mathrm{N}_{2}$ fixation has been focused on the filamentous cyanobacteria Trichodesmium (Capone et al., 2005). However, due to the absence of diazotrophic Trichodesmium populations during this cruise, we can postulate that $\mathrm{N}_{2}$-fixation was executed by nanoplanktonic and picoplanktonic organisms, recently revealed by new molecular biological techniques (Zehr et al., 1998, 2000) and by direct measurements (Montoya et al., 2004; Garcia et al., 2007; Biegala and Raimbault, 2008). The discovery of potentially important marine diazotrophs other than Trichodesmium opens up a new area when studying the importance of nitrogen fixation in the ocean. Due to their ability to fix $\mathrm{N}$, these nanoplanktonic cyanobacteria can contribute substantially to the input of new nitrogen into nutrient-depleted waters, even if the rates of fixation measured are typically quite low relative to the apparent $\mathrm{N}$ demand of the ecosystem. Our integrated values (30-910 $\mu \mathrm{mol} \mathrm{m}^{-2} \mathrm{~d}^{-1}$ ) are the same order of magnitude as found in the literature concerning dinitrogen fixation by nanoplankton, with the exception of the high value $\left(3955 \mu \mathrm{mol} \mathrm{m}^{-2} \mathrm{~d}^{-1}\right.$ ) found along the Australian coasts by Montoya et al. (2004). Zehr et al. (2001) give an integrated value of $92 \mu \mathrm{mol} \mathrm{m}^{-2} 12 \mathrm{~h}^{-1}$ for the North Pacific. This value is a little higher than those measured by Montoya et al. (2004) in the same region (24-66 $\mu \mathrm{mol} \mathrm{m}^{-2} \mathrm{~d}^{-1}$ ). Similar results have been found in the Southwest Pacific around New Caledonia (Garcia et al., 2007), with nitrogen fixation occurring in the $<10 \mu \mathrm{m}$ fraction, i.e. not associated with Trichodeminum populations, ranging from 40
$300 \mu \mathrm{mol} \mathrm{m}^{-2} \mathrm{~d}^{-1}$. Falcon et al. (2004) found a daily range of $62-167 \mu \mathrm{mol} \mathrm{m}^{-2} \mathrm{~d}^{-1}$ for the north Atlantic. Recent equivalent rates $\left(\approx 50 \mu \mathrm{mol} \mathrm{m}^{-2} \mathrm{~d}^{-1}\right)$ were obtained in the Mediterranean Sea during the oligotrophic summer period (Garcia et al., 2006), representing up to $40 \%$ of new production. These small nanoplanktonic cyanobacteria were not observed during the BIOSOPE cruise. But high density populations of phycoerythrin containing cyanobacteria were detected along the transect, with a maximum being observed in the Chilean upwelling, and most of these cyanobacteria (up to $50 \%$ in the SPG) forming colonies (Masquelier and Vaulot, 2007). Thus, as suggested by these authors, it is tempting to hypothesize that these colonial cyanobacteria could be the organisms responsible of the observed $\mathrm{N}_{2}$-fixation. $\mathrm{N}_{2}$-fixation sustained a large fraction of new production (up to 100\%) in the oligotrophic SPG and this nitrogen pool represents a potentially important nitrogen source for other organisms in the pelagic food web, especially where any input of other forms of new nitrogen is excluded. The light $\delta^{15} \mathrm{~N}$ isotopic signal observed in the SPG (Raimbault et al., 2007) suggests that nitrogen fixation provides a local dominant supply of nitrogen to phytoplankton in this isolated region, where the vertical flux of nitrate from below the thermocline is extremely low due to the deep thermocline. Finally, our observations confirmed the global distribution diagnosed by Deutsch et al. (2007), providing evidence that elevated $\mathrm{N}_{2}-$ fixation rates are closely linked to areas of denitrification, as encountered along the Peruvian and Chilean coasts. According to the model of Deutsch et al. (2007), annual fixation rates in the SPG and in the Chilean upwelling range from 40-160 mmoles $\mathrm{m}^{-2} \mathrm{y}^{-1}$ and 20-120 mmoles $\mathrm{m}^{-2} \mathrm{y}^{-1}$, respectively. Our direct measurements, assuming no seasonal variation, are at the low end of these ranges $\left(22 \pm 12\right.$ mmoles $^{-2} \mathrm{y}^{-1}$ and $33 \pm 22$ mmoles $^{-2} \mathrm{y}^{-1}$, respectively). The basin scale $\mathrm{N}_{2}$-fixation for the South Pacific Gyre, representing $1.1 \%$ of the global oceanic surface $\left(4.10^{6} \mathrm{~km}^{2}\right)$, is estimated to be about $1.34 \times 10^{12} \mathrm{~g} \mathrm{~N} \mathrm{y}^{-1}$ and corresponds to about $1 \%$ of the global $\mathrm{N}_{2}$-fixation calculated by Deutsch et al. (2007). Finally, our direct estimates of $\mathrm{N}_{2}$ fixation for the entire South Pacific basin $\left(21.10^{12} \mathrm{~g} \mathrm{yr}^{-1}\right)$ was two folds lower than expected by Deutsch et al. (2007). This apparent inconsistency could be due to uncertainties regarding ocean circulation and precise nutrient distribution (Deutsch et al., 2007) and also seasonal variations of $\mathrm{N}_{2}$ fixation as observed in the southwest and North Pacific (Garcia et al., 2007; Dore et al., 2002). Nevertheless, our basinscale budget are close to recent estimates for the North Atlantic Ocean $\left(4.2\right.$ to $85 \times 10^{12} \mathrm{~g} \mathrm{yr}^{-} 1$, complied in Hansell et al., 2007), considered as an important region of $\mathrm{N}_{2}$ fixation given the enhanced inputs of atmospheric dust from the Sahara. This indicates that the South Pacific Ocean would provide an ideal ecological niche for the proliferation of $\mathrm{N}_{2}$ fixers (still unknown), even if our "snapshot" estimates of $\mathrm{N}_{2}$-fixation rates were lower than could be expected from the ocean circulation model. Finally, oceanic N-fixation is a 
process which is more important than initially thought and not restricted to the warm- and nutrient-depleted tropical areas. This source of new nitrogen will support net production and export of organic matter from the euphotic zone, with a direct effect on the carbon cycle. This fact leads to relevant consequences in relation to the $\mathrm{N}_{2}$ fixation-climate feedback hypothesis proposed by Michaels et al. (2001). Clearly, the budget of $\mathrm{N}_{2}$ fixation remains highly uncertain and so more widespread research needs to be carried out on marine $\mathrm{N}$ fixers in order to quantify their role in the global oceanic biogeochemistry cycle.

Acknowledgements. This is a contribution of the BIOSOPE project of the LEFE-CYBER program, funded by the Centre National de la recherche Scientifique (CNRS), the Institut des Sciences de l'Univers (INSU), the Centre National d'Etudes Spatiales (CNES), The European Space Agency (ESA), the National Aeronautics and Space Administration (NASA) and the natural Sciences and Engineering Research Council of Canada (NSERC). This work is fund in part by the French Research and Education Council. The Biosope cruise program was managed by $\mathrm{H}$. Claustre and A. Sciandra. We thank the crew of the R/V Atalante for outstanding shipboard support operations. Data concerning euphotic layer depth and surface light intensity were kindly provided by H. Claustre. D. Taillez and C. Bournot are warmly thanked for their efficient help in CTD rosette management and data processing. J. C. Miquel provided sediment trap data, and T. Moutin provided data of primary production from ${ }^{14} \mathrm{C}$ experiments. The authors gratefully thank the two anonymous referees who helped to make substantial improvements in the manuscript and T. Bentley for her linguistic and scientific advice.

Edited by: S. W. A. Naqvi

\section{References}

Allen, A. E, Howard-Jones, M. H., Booth, M. G., Frischer, M. E., Verity, P. G., Bronk, D. A., Sanderson, M. P: Importance of heterotrophic bacterial assimilation of ammonium and nitrate in the Barents Sea during summer, J. Marine Syst., 38, 93-108, 2002.

Altabet, M.: Organic C, N and stable isotopic composition of particulate matter collected on glass-fibber and aluminum oxide filters, Limnol. Oceanogr., 35(4), 902-909, 1990.

Aufdenkampe, A. K., McCarthy, J. J., Rodier, M., Navarrette, C., Dunne, J., and Murray, J. W.: Estimation of new production in the Tropical Pacific, Global Biogeochem. Cy., 15, 101-113, 2001.

Aufdenkampe, A. K., McCarthy, J. J., Navarrette, C., Rodier, M., Dunne, J., and Murray, J. W.: Biogeochemical controls on new production in the tropical pacific, Deep. Sea. Res. II, 49, 26192648, 2002.

Béthoux, J. P. and Copin-Montégut, G.: Biological fixation of atmospheric nitrogen in the Mediterranean Sea, Limnol. Oceanogr., 31, 1353-1358, 1986.

Bianchi, M., Feliatra, F., Tréguer, P., Vincendeau, M., and Morvan, J.: Nitrification rates, ammonium and nitrate distribution in upper layers of the water column and in sediments of the Indian sector of the Southern Ocean, Deep Sea Res. II, 44(5), 10171032, 1997.

Biegala, I. C. and Raimbault, P.: High abundance of diazotrophic picocyanobacteria $(<3 \mu \mathrm{m})$ in a South-West Pacific coral lagoon, Aquat. Microb. Ecol., in press, 2008.

Bode, A., Castro, C., Doval, M. D., and Varela, M.: New and regenerated production and ammonium regeneration in the western Bransfield region (Antarctica) during phytoplankton bloom conditions in summer, Deep Sea Res. II, 49, 787-804, 2002.

Bronk, D. A. and Glibert, P.: A ${ }^{15} \mathrm{~N}$ tracer method for the measurement of dissolved organic nitrogen release by phytoplankton, Mar. Ecol. Prog. Ser., 77, 171-182 1991.

Bronk, D. A., Glibert, P., and Ward, B. B.: Nitrogen uptake, dissolved organic nitrogen release and new production, Science, 256, 1843-1846, 1994.

Capone, D. G. and Carpenter, E. J.: Nitrogen fixation in the marine environment, Science, 217, 1140-1142, 1982.

Capone, D. G., Burns, J. A, Montoya, J. P., Subramaniam, A., Mahaffey, C., Gunderson, T., Michaels, A. F., and Carpenter, E. J.: Nitrogen fixation by Trichodesmium spp.: An important source of new nitrogen to the tropical and subtropical North Atlantic Ocean, Global Biogeochem. Cy., 19, GB2024, doi:10.1029/2004GB002331, 2005.

Carlson, C. A., Ducklow, H. W., and Michaels, A. F.: Annual flux of dissolved organic carbon from the euphotic zone in the northwestern Sargasso Sea, Nature, 371, 405-408, 1994.

Chavez, F. P., Buck, K. R., Bidigare, R. R., Karl, D. M., Hebel, D., Latasa, M., and Campbell, L.: On the chlorophyll a retention properties of glass-fiber GF/F filters, Limnol. Oceanogr., 40, 428-433, 1995.

Claustre, H. and Maritorena, S.: Ocean Science: The many shades of ocean blue, Science, 302, 1514-1515, 2003.

Codispoti, L. A. and Christensen, J. P.: Nitrification, denitrification and nitrous oxide cycling in the eastern tropical South Pacific Ocean, Mar. Chem., 16(4), 277-300, 1985.

Copin-Montégut, G. and Avril, B.: Vertical distribution and temporal varaition of dissolved organic carbon in the North-Western Mediterranean Sea, Deep-Sea Res., 40, 1963-1972, 1993.

Daneri, G. and Quinones, R. A.: Undersamples ocean systems: appeal for an international study of biogeochemical cycles in the Southern Pacific gyre and its boundaries, U.S. JGOFS Newsletter January 2001, 9, 2001.

Deutsch, C., Sarmiento, J.L, Sigman, D. M., Gruber, N., and Dunne, J. P.: Spatial coupling of nitrogen inputs and losses in the ocean, 445(7124), 163-167, 2007.

Diaz, F. and Raimbault, P.: Nitrogen regeneration and dissolved organic nitrogen release during spring in a NW Mediterranean coastal zone (Gulf of Lions): implications for the estimations of f-ratio and new production, Mar. Ecol. Progr. Ser., 197, 53-66, 2000.

Dore, J. E. and Karl, D. M.: Nitrification in the euphotic zone as a source of nitrite, nitrate, and nitrous oxide at Station ALOHA, Limnol. Oceanogr., 41, 1619-1628, 1996.

Dore, J. E., Brum, J. R., Tupas, L. M., and Karl, D. M.: Seasonal and interannual variability in sources of nitrogen supporting export in the oligotrophic subtropical North Pacific Ocean, Limnol. Oceanogr., 47(6), 1595-1607, 2002.

Dugdale, R. C. and Goering, J. J.: Uptake of new and regenerated forms of nitrogen in primary productivity, Limnol. Oceanogr., 
12, 196-206, 1967.

Dugdale, R. W. and Wilkerson, F. P.: The use of ${ }^{15} \mathrm{~N}$ to measure nitrogen uptake in eutrophic oceans: experimental considerations, Limnol. Oceanogr., 31, 673-689, 1986.

Dugdale, R. W., Wilkerson, F. P., Chavez, F. P., and Barber, R. T.: Estimating new production in the equatorial Pacific at $150^{\circ} \mathrm{W}, \mathrm{J}$. Geophys. Res., 97, 681-686, 1992.

Dugdale, R. C. and Goering, J. J.: Uptake of new and regenerated forms of nitrogen in primary productivity, Limnol. Oceanogr., 12, 196-206, 1967.

Dugdale, R. C. and Wilkerson, F. P.: The use of ${ }^{15} \mathrm{~N}$ to measure nitrogen uptake in eutrophic oceans, experimental considerations, Limnol. Oceanogr., 31(4), 673-689, 1986.

Dugdale, R. C., Wilkerson, F. P., Barber, R., and Chavez, F.: Estimating new production in the equatorial Pacific Ocean at $150^{\circ} \mathrm{W}$, J. Geophys. Res., 97(C1), 681-686, 1992.

Eppley, R. W. and Peterson, B. J.: Particulate organic matter flux and planktonic new production in the deep ocean, Nature, 282, 677-680, 1979.

Falcon, L. I., Carpenter, E. J., Cipriano, F., Bergman, B., and Capone, D. G.: N2 fixation by unicellular bacterioplankton from the Atlantic and pacific oceans: phylogeny and in situ rates, Appl. Environ. Microbiol., 765-770, 2004.

Fernandez, C. and Raimbault, P.:. Nitrogen regeneration in the NE Atlantic Ocean and its impact on seasonal new, regenerated and export production, Mar. Ecol. Progr. Ser., 337, 79-92, 2007.

Galloway, J. N., Schlesinger, W. H., Levy, H., Michaels, A., and Schnoor, J. L.: Nitrogen fixation: Anthropogenic enhancementenvironmental response, Global Biogeochem. Cy., 9, 235-252, 1995.

Garcia, N., Raimbault, P., Gouze, E., and Sandroni, V.: Dinitrogen fixation and primary production in Western Mediterranean Sea, C. R. Biol., 329(9), 742-750, 2006.

Garcia, N., Raimbault, P., and Sandroni, V.: Seasonal nitrogen fixation and primary production in Southwest Pacific (New Caledonia): Some evidence for nanoplanktonic diazotrophy and rapid transfer of newly fixed nitrogen to picoplankton organisms, Mar. Ecol. Progr. Ser., 343, 25-33, 2007.

Gentilhomme, V. and Raimbault, P.: Absorption et régénération de l'azote dans a zone frontale du courant algérien (Méditerranée Occidentale): Réévaluation de la production nouvelle, Oceanol. Acta., 17, 555-562, 1994.

Glibert, P. M., Lipschultz, F., McCarthy, J. J., and Altabet, M. A.: Isotope dilution models of uptake and remineralization of ammonium by marine plankton, Limnol. Oceanogr., 27, 639-650, 1982.

Grob, C., Ulloa, O., Claustre, H., Huot, Y., Alarcón, G., and Marie, D.: Contribution of picoplankton to the total particulate organic carbon concentration in the eastern South Pacific, Biogeosciences, 4, 837-852, 2007, http://www.biogeosciences.net/4/837/2007/.

Grüber, N. and Sarmiento, J.: Global patterns of marine nitrogen fixation and denitrification, Global Biogeochem. Cy., 11, 235266, 1997.

Hansell, D. A. Olson, D. B., Dentener, F., and Zamora, L. M.: Assessment of excess nitrate development in the subtropical North Atlantic, Mar. Chem., 106, 562-579, doi:10.1016/j.marchem, 2007.

Harrison, W. G., Platt, T., and Lewis, M. R.: f-ratio and its relation- ship to ambient nitrate concentration in coastal waters, J. Plankton Res., 9(1), 235-248, 1987.

Harrison, W. G., Harris, L. R., and Irwin, B. D.: The kinetic of nitrogen utilization in the oceanic mixed layer: nitrate and ammonium interactions at nanomolar concentrations, Limnol. Oceanogr., 41, 16-32, 1996.

Holmes, M. R., Aminot, A., Kerouel, R., Hooker, B. A., and Peterson, J. B.: A simple and precise method for measuring ammonium in marine and freshwater ecosystems, Can. J. Fish Aquat. Sci., 56, 1801-1808, 1999.

Karl, D. M.: Nutrients dynamics in the deep blue sea, Trends Microbiol. 10, 410-418, 2002.

Karl, D. M., Michaels, A., Bergman, B., et al.: Dinitrogen fixation in the world's oceans, Biogeochemistry, 57/58, 47-98, 2002.

Karl, D. M., Letelier, R., Tupas, L., Dore, J., and Christian, J. D. H.: The role of nitrogen fixation in biochemical cycling in the subtropical North Pacific Ocean, Nature, 386, 533-538, 1997.

Laws, E.: Isotope dilution models and the mistery of the vanishing 15N, limnol. Oceanogr., 29, 379-386, 1984.

Libby, P. S. and Wheeler, P. A.: Particulate and dissolved organic nitrogen in the central and eastern Equatorial Pacifi, Deep-Sea Res., 44, 345-361, 1996.

Lomas, M. W. and Lipschultz, F.: Forming the primary nitrite maximum: nitrifiers or phytoplankton?, Limnol. Oceanogr., 51, 2453 2467, 2006.

Mahaffey, C., Michaels, A. F., and Capone, D. G.: The conundrum of marine nitrogen fixation, Am. J. Sci., 305, 546-595, 2005.

Mahowald, N.: Dust sources and deposition during the last glacial maximum and current climate: A comparison of model results with paleodata from ice cores and marine sediments, J. Geophys. Res.-Atmos., 104, 15 895-15 916, 1999.

Maita, Y. and Yanada, M.: Vertical distribution of total dissolved nitrogen and dissolved organic nitrogen in seawater, Geochem. J., 24, 245-254, 1990.

Masquelier, S. and Vaulot, D.: Distribution of micro-organisms along a transect in the South-East Pacific Ocean (BIOSOPE cruise) from epifluorescence microscopy, Biogeosciences Discuss., 4, 2667-2697, 2007, http://www.biogeosciences-discuss.net/4/2667/2007/.

Menzel, D. W. and Ryther J. H.: The annual cycle of primary production in the Sargasso Sea off Bermuda, Deep Sea Res., 6, 351367, 1960.

Menzel, D. W. and Ryther, J. H.: The composition of particulate organic matter in the western north Atlantic, Limnol. Oceanogr., 9, 179-186, 1964.

Michaels, A. F., Karl, D. M., and Capone, D. G.: Element stoichiometry, new production and nitrogen fixation, Oceanography, 14, 68-77, 2001.

Montoya, J. P., Voss, M., Kähler, P., and Capone, D. G.: A simple, high precision, high sensitivity tracer assay for $\mathrm{N}_{2}$ fixation, Appl. Environ. Microb., 62, 986-993, 1996.

Montoya, J. P., Holl, C. M., Zehr, J. P., Hansen, A., Villareal, T. A., and Capone, D. G.: High rates of N2 fixation by unicellular diazotrophs in the oligotroph Pacific, Nature, 430, 1027-1031, 2004.

Morel, A. and Maritorena, S.: Bio-optical properties of oceanic waters: a reappraisal, J. Geophys. Res., 106(C4), 7163-7180, 2001.

Morel, A., Gentili, B., Claustre, H., Babin, M., Bricaud, A., Ras, J., and Tieche, F.: Optical properties of the clearest natural waters, 
Limonl. Oceanogr., 52, 217-229, 2007.

Nixon, S. W.: Coastal eutrophication: a definition, social causes and future concerns, Ophelia, 41, 199-220, 1995.

Peltzer, E. T. and Hayward, N. A.: Spatial and temporal variability of total organic carbon along the $140^{\circ} \mathrm{W}$ in the equatorial Pacific ocean in 1992, Global Biogeochem. Cy., 6, 45-76, 1996.

Platt, T. and Harison, W. G.: Biogennic fluxes of carbon and oxygen in the ocean, Nature, 318, 55-58, 1985.

Priscu, J. C. and Downes, M. T.: Nitrogen uptake, ammonium oxidation and nitrous oxide $\left(\mathrm{N}_{2} \mathrm{O}\right)$ levels in the coastal waters of western Cook Strait, New Zealand, Estuary. Coast Shel Sci., 20, 529-542, 1985.

Procter, L. M. and Fuhrman, J. A.: Viral mortality of marine bacteria and cyanobacteria, Nature, 343, 1327-1332, 1990.

Raimbault, P., Slawyk, G., Coste, B., and Fry, J.: Feasibility of using an automated colorimetric procedure for the determination of seawater nitrate in the 0 to $100 \mathrm{nM}$ range: Examples from field and culture, Mar. Biol., 104, 347-351, 1990.

Raimbault, P., Garcia, N., and Cerutti, F.: Distribution of inorganic and organic nutrients in the South Pacific Ocean - evidence for long-term accumulation of organic matter in nitrogen-depleted waters, Biogeosciences Discuss., 4, 3041-3087, 2007, http://www.biogeosciences-discuss.net/4/3041/2007/.

Raimbault, P., Slawyk, G., Boudjellal, B., Coatanoan, C., Conan, P., Coste, B., Garcia, N., Moutin, T., and Pujo-Pay, M.: Carbon and nitrogen uptake and export in the equatorial pacific at $150^{\circ} \mathrm{W}$ : Evidence of an efficient regenerated production cycle, J. Geophys. Res., 104(C2), 3341-3356, 1999.

Raimbault, P., Slawyk, G., and Garcia, N.: Comparison between chemical and isotopic measurements of biological nitrate utilization: further evidence of low new production levels in the equatorial Pacific, Mar. Biol., 136, 1147-1155, 2000.

Ras, J., Claustre, H., and Uitz, J.: Spatial variability of phytoplankton pigment distributions in the Subtropical South Pacific Ocean: comparison between in situ and predicted data, Biogeosciences Discuss., 4, 3409-3451, 2007, http://www.biogeosciences-discuss.net/4/3409/2007/.

Redfield, A. C., Ketchum, B. H., and Richards, F. A: The influence of organisms on the composition of seawater, in: The Sea, edited by: Hill, M. N., Wiley, 26-77, 1963.

Rees, A. P., Joint, I., and Donald, D. M.: Early spring bloom phytoplankton-nutrient dynamics at the celtic Sea Shelf edge, Deep Sea Res., 46, 483-510, 1999.

Ryther, J. H. and Menzel, D. W.:. The seasonal and geographical range of primary production in the Western Sargasso sea, Deep Sea Res., 6, 235-238, 1960.

Sahlsten, E.: Nitrogenous nutrition in the euphotic zone of the central North pacific Gyre, Mar. Biol., 96, 433-439, 1987.

Slawyk, G. and Collos, Y.: ${ }^{13} \mathrm{C}$ and ${ }^{15} \mathrm{~N}$ uptake by marine phytoplankton III. Interactions in euphotic zone profiles of stratified oceanic areas, Mar. Ecol. Prog. Ser. 19, 223-231, 1984.

Slawyk, G. and Raimbault, P.: Simple procedure for the simultaneous recovery of dissolved inorganic and organic nitrogen in ${ }^{15} \mathrm{~N}$-tracer experiments and improving the isotopic mass balance, Mar. Ecol. Prog. Ser., 124, 289-299, 1995.
Slawyk, G., Raimbault, P., and Garcia, N.: Measuring gross uptake of ${ }^{15} \mathrm{~N}$ labeled nitrogen by marine phytoplankton without particulate matter collection: Evidence of low ${ }^{15} \mathrm{~N}$ losses to the dissolved organic nitrogen pool, Limnol. Oceanogr., 43(7), 1734 1739, 1998.

Slawyk, G., Raimbault, P., and Garcia, N.: Use of ${ }^{15} \mathrm{~N}$ to measure dissolved organic nitrogen release by marine phytoplankton (reply to comment by Bronk and Ward), Limnol. Oceanogr., 45(8), 884-1886, 2000.

Tedetti, M., Sempéré, R., Vasilkov, A., Charrière, B., Nérini, D., Miller, W. L., Kawamura, K., and Raimbault, P.: High penetration of ultraviolet radiation in the South East Pacific waters, Geophys. Res. Lett., 34, L12610, doi: 10.29/2007/GL029823, 2007.

Toggeweiler, J. R.: Is the downward dissolved organic matter (DOM) flux important in carbon export, in: Productivity of the ocean: Present and past, edited by: Berger, W. H., Smetacek, V. S., and Wefer, G., Wiley-Intersci., New-York, 65-84, 1989.

Tréguer, P. and LeCorre, P.: Manuel d'analyses des sels nutritifs dans l'eau de mer: Utilisation de l'Autoanalyser II Technicon, Univ. of Bretagne Occidentale, Lab. de Chim. Mar., Brest, France, 1975.

Ward, B. B.: Nitrification and the marine nitrogen cycle, in: Microbial ecology of the oceans, edited by: Kirchman, D., Wiley-Liss Inc., 427-454, 2000.

Ward, B. B., Talbot, M. C., and Perry, M. J.: Contributions of phytoplankton and nitrifying bacteria to ammonium and nitrite dynamics in coastal waters, Cont. Shelf. Res., 3, 383-398, 1984.

Ward, B. B., Kilpatrick, K. A., Renger, E. H., and Eppley, R. W.: Biological nitrogen cycling in the nitracline, Limnol. Oceanogr., 34(3), 493-513, 1989.

Ward, B. B. and Zafiriou, O. C.: Nitrification and nitric oxide in the oxygen minimum of the eastern tropical North Pacific, Deep Sea Res., 35(7), 1127-1442, 1988.

Weiss, R. F.: The solubility of nitrogen, oxygen and argon in water and seawater, Deep Sea-Res., 17, 721-735, 1970.

Zehr, J. P., Mellon, M. T., and Zani, S.: New nitrogen fixing microorganisms detected in oligotrophic oceans by the amplification of nitrogenase (nifH) genes, Appl. Environ. Microbiol., 64, 3444-3450, 1998.

Zehr, J. P, Carpenter, E. J., and Villareal, T. A.: New perspectives on nitrogen-fixing microorganisms in tropical and subtropical oceans, Trends Microbiol., 8, 68-73, 2000.

Zehr, J. P. and Ward, B. B.: Nitrogen cycling in the Ocean: New perspectives on processes and paradigms, Appl. Environ. Microbiol., 68(3), 1015-1024, 2002.

Zehr, J. P., Waterbury, J. P., Turner, P. J., Montoya, J. P., Omoregie, E., Steward, G. F, Hansen, A., and Karl, D. M.: Unicellular cyanobacteria fix N2 in the subtropical North Pacific Ocean, Nature, 412 635-638, 2001. 